\title{
Chromatin-Level Differences Elucidate Potential Determinants of Contrasting Levels of Cold Sensitivity in Maize Lines
}

\author{
Maciej Jończyk $^{1}$ (1) Alicja Sobkowiak ${ }^{1}$ (D) Joanna Trzcinska-Danielewicz ${ }^{2}$ (D) Paweł Sowiński ${ }^{1}$ (D)
}

Received: 12 May 2020 / Accepted: 8 October 2020 / Published online: 19 October 2020

(C) The Author(s) 2020

\begin{abstract}
Maize is a subtropical, cold-sensitive species. However, some varieties of this species have the potential to withstand long-term low temperatures, even at the seedling stage. The molecular basis of this phenomenon has not been determined. In a chromatinlevel study, we compared the cold-stress reaction of seedlings of two maize inbred lines showing contrasting levels of cold sensitivity. The cold-tolerant line was selected based on field data and previous physiological and transcriptomic level studies. The first condition of gene expression — chromatin accessibility — was assessed by formaldehyde-aided isolation of regulatory elements method and DNA sequencing. Potentially expressed genes and cis-regulatory sequences open for interaction with transcription factors have been defined. The results of this study suggest that during cold stress, the tolerant maize line shifted resources from growth to defense. This shift was shown by potential hormone-level events - degradation of growth-promoting gibberellins and synthesis of jasmonic and abscisic acids. This finding is congruent with the xeromorphic morphology of seedlings of the cold-tolerant line and their ability to regrow when stress ceases. It is a common reaction of cold-tolerant maize lines. Moreover, in the cold-tolerant line, several genes from the low-temperature signaling pathways were potentially expressed. Additionally, numerous stress-response AP2/EREBP-binding cis-motifs were accessible in the cold-tolerant line. Differently in the cold-sensitive B73 line, MADS-binding cis-motifs were the most abundant. Development of the photosynthetic apparatus is crucial for the survival of maize seedlings at low temperature. Our results suggest efficient photosynthesis in seedlings of the cold-tolerant line, as was described earlier in physiological-level analyses.
\end{abstract}

Keywords Cold tolerance $\cdot$ Chromatin $\cdot$ Maize $\cdot$ Stress $\cdot$ Seedling $\cdot$ Low temperature

Key message Cold sensitivity differences between two maize inbred lines were studied. The potential shift of gibberellin-jasmonic acid hormonal balance favoring the latter has been found in cold-tolerant line. Consequently, a shift to defense may explain the outstanding cold tolerance of seedlings of some maize varieties bred in temperate climates.

Electronic supplementary material The online version of this article (https://doi.org/10.1007/s11105-020-01254-7) contains supplementary material, which is available to authorized users.

Maciej Jończyk

mjonczyk@biol.uw.edu.pl

1 Department of Plant Molecular Ecophysiology, Institute of Plant Experimental Biology and Biotechnology, Faculty of Biology, University of Warsaw, Miecznikowa 1, 02-096 Warsaw, Poland

2 Department of Molecular Biology, Institute of Biochemistry, Faculty of Biology, University of Warsaw, Warsaw, Poland

\section{Introduction}

During seedling establishment, hardy seeds transform into autotrophic plants. This process requires the production of new leaves and the development of the photosynthetic apparatus, as well as the ability to withstand unfavorable conditions. The earliest stages of plant life are critical from the agricultural perspective, as seedling performance is a foundation of successful growth and eventual yield. Therefore, it is necessary to determine both the physiological and molecular bases of the earliest seedling growth. This research is crucial in the case of warm climate species cultivated in the temperate climate. One such species is maize (Zea mays L.), which attracts exceptional interest due to its efficient $\mathrm{C} 4$ photosynthesis and notably high productivity under optimal conditions (Osborne and Sack 2012). Maize seedlings at the earliest stages of development are highly cold-sensitive (Leipner and Stamp 2009; Frascaroli and Revilla 2018). There is considerable variation in cold sensitivity among maize inbred lines 
(Verheul et al. 1996; Strigens et al. 2013; Sobkowiak et al. 2014, 2016; Grzybowski et al. 2019). However, the molecular-level basis of this trait has not been fully elucidated. Maize is a highly variable species at the genome level, and inbred lines differ in gene content (Swanson-Wagner et al. 2010 and references therein).

Molecular level studies on maize showed that cold-stress leads to profound transcriptome changes. Notably, induction of gene expression dominated over repression in cold-stressed seedlings of tolerant line S68911 relative to control (Sobkowiak et al. 2016). One of the common physiological level changes in cold-stressed maize is inhibition of photosynthesis (Leipner and Stamp 2009). Interestingly, seedlings of some maize lines showed induction of expression of chloroplast genes in cold conditions (Nguyen et al. 2009; Zhang et al. 2009; Sobkowiak et al. 2016) what could maintain relatively high level of photosynthesis (Sobkowiak et al. 2016; Grzybowski et al. 2019). Protein products of many genes highly expressed in cold in tolerant maize lines have predicted localization in cell wall and membranes, including plasmalemma (Sobkowiak et al. 2014, 2016). Plasma membrane is a site of cold reception (Leipner and Stamp 2009) and is linked functionally with other highly expressed gene categories in tolerant lines, namely transport and signal transduction (Nguyen et al. 2009; Zhang et al. 2009; Sobkowiak et al. 2014, 2016). Cold stress had strong effect on synthesis and signaling of many hormones, as microarray study has shown (Sobkowiak et al. 2014). However, in most cases, both positive and negative hormonal regulation have been observed in maize seedlings. The exception were genes responsible for ethylene biosynthesis and auxin response factors (ARFs), induced in both two maize lines of different cold sensitivity (Sobkowiak et al. 2014). Notably, the majority of data on the molecular level reaction of maize to cold was obtained in studies on fully developed autotrophic third leaf of seedlings (V3 stage, when the collar of the third leaf is visible, Ritchie et al. (1986)). However, during growth in the temperate climate younger maize seedlings can also experience low temperature, so these stages are equally important in research on maize cold sensitivity (Grzybowski et al. 2019).

Gene expression is regulated at several levels. The first is physical chromatin accessibility. Subsequent levels comprise transcription, mRNA translation, and posttranslational modifications of proteins. Among those levels, the regulation of chromatin accessibility is the least thoroughly characterized. The compact form of chromatin limits DNA accessibility for regulatory proteins and, consequently, the genome available for transcription. The functional genome could amount to only $1 \%$ in maize (Rodgers-Melnick et al. 2016). This property is, in part, an effect of a large proportion of noncoding DNA (Schnable et al. 2009), but the functional genome can be strongly influenced by multiple cues, such as developmental transitions (Candaele et al. 2014; Perduns et al. 2015) and stress. It was shown that heat and cold stress have caused histone acetylation and, consequently, chromatin decondensation in maize leaves ( $\mathrm{Hu}$ et al. 2012; Wang et al. 2015). Additionally, water stress has induced chromatin-level changes in various plant species (Han and Wagner 2014). Importantly, chromatin-level regulation has been shown for the crucial element of the drought response in maize, $Z$. mays dehydration responsive element binding 2A (ZmDREB2A, Zhao et al. 2014). The same finding was observed for Oryza sativa dehydration responsive element binding $1 B$, which is important in the response of rice to cold (OSDREB1B, Roy et al. 2014). Nucleosome-depleted regions (NDRs) just upstream genes are correlated with their expression level in many eukaryotic organisms, including maize (Hogan et al. 2006; Vera et al. 2014; Rodgers-Melnick et al. 2016; Oka et al. 2017). Determination of NDRs not only provides information on potentially expressed genes but also, more importantly, uncovers the key DNA sequences for gene expression regulation, enabling the construction of gene regulatory networks.

The aim of this study was to determine cold-induced changes in the nucleosome occupancy level of DNA in maize seedlings, and define potentially expressed genes important in cold tolerance. The performance of two maize inbred lines with contrasting cold sensitivity was compared. The coldtolerant S68911 line, which is adapted to the temperate climate (Sobkowiak et al. 2016; Grzybowski et al. 2019), and the reference B73 line, which is cold-sensitive (Joets et al. 2018; Grzybowski et al. 2019), were used. The S68911 line shows high early vigor in cold spring conditions in the field (Grzybowski et al. 2019). When grown from kernels in growth chamber in prolonged cold conditions, S68911 seedlings develop normally, although they exhibit xeromorphic morphology, as has been observed in Grzybowski et al. (2019) and in this study. Xeromorphy has also been shown for other cold-tolerant maize lines grown in cold conditions (Verheul et al. 1996; Sowiński et al. 2003; Strigens et al. 2013; Grzybowski et al. 2019). This growth form has been postulated to prevent water loss and secondary water stress (Strigens et al. 2013). Under cold conditions, B73 plants are retarded, develop only two faint-green leaves, cease to grow, and die (Riva-Roveda et al. 2016; Grzybowski et al. 2019).

The study focused on early maize development; therefore, the first leaves of the seedlings were sampled at three growth stages. Development of the photosynthetic apparatus at the seedling stage determines the survival of the plant in the cold (Grzybowski et al. 2019). The regions of open chromatin (NDRs) were determined using the formaldehyde-aided isolation of regulatory elements (Omidbakhshfard et al. 2014) and sequencing (FAIRE-seq) method. 


\section{Materials and Methods}

\section{Growth Conditions and Plant Material}

Two maize inbred lines with contrasting cold sensitivity were used. We previously examined the cold-tolerant S68911 line at physiological and transcriptomic levels (Sobkowiak et al. 2016; Grzybowski et al. 2019). The B73 line was chosen as a reference because it is cold-sensitive (Joets et al. 2018; Grzybowski et al. 2019) and its genome has been de novo sequenced (Schnable et al. 2009). Kernels of the S68911 line were provided by Prof. Józef Adamczyk (Plant Breeding Smolice Co. Ltd., Poland). Kernels of the B73 line were obtained from Maize Genetics Cooperation Stock Center (USA) and were propagated in a greenhouse at the Faculty of Biology, University of Warsaw (Poland). In this work, we investigated the regulation-level basis of the outstanding cold tolerance of the S68911 maize line.

Plants were grown from kernels in a growth chamber under a $14 \mathrm{~h} / 10 \mathrm{~h}$ photoperiod with light irradiance of $500 \mu \mathrm{mol}$ quanta $\mathrm{m}^{-2} \mathrm{~s}^{-1}$ during the light phase and $70 \%$ air relative humidity. The temperature was set according to treatment (control, cold, day/night temperature $24{ }^{\circ} \mathrm{C} / 20^{\circ} \mathrm{C}$ and $14{ }^{\circ} \mathrm{C} / 10{ }^{\circ} \mathrm{C}$, respectively) from the start of the experiment. For plant growth, special installation was used, consisting of impermeable polyvinyl chloride tubes packed with soil and placed in a container filled with water (for full description, see Grzybowski et al. 2019). The water was cooled by a thermostat, which enabled the soil temperature to be controlled. The thermostat was set so that the soil temperature was the same as the air temperature. There were 10-12 plants per tube, and the plants were watered as needed with tap water. The position of the tubes in the container was randomized several times during the experiment to cancel the effects of the potential temperature gradient in the growth chamber. Three biological replicates of the experiment were conducted. Samples were taken at three growth stages: coleoptile (VE); seedling with the tip of the second leaf visible ("VE/V1" stage); seedling with the first leaf fully developed (V1, when the collar of the first leaf is visible). Stages were described according to Ritchie et al. (1986). The sampling relied on developmental stage and not on time because in cold conditions, the growth of plants is retarded. Each sample consisted of pooled material from at least three plants (coleoptile for VE, first leaf for VE/ $\mathrm{V} 1$ and V1 stages). The samples were flash-frozen in liquid nitrogen and stored at $-80{ }^{\circ} \mathrm{C}$ until further processing.

\section{Isolation of Nucleosome-Free DNA}

Nucleosome-free DNA was extracted according to the FAIRE procedure (Omidbakhshfard et al. 2014). The DNA samples were sonicated into $200-800$ bp fragments. During sonication, the samples were kept on ice. The procedure consisted of ten 15-s pulses with 2-min breaks between them to prevent heating of the samples. Kontes KT-50 Micro Ultrasonic Cell Disrupter (Walker F.C. Ebel, Germany) was used with an output set at 55. Phase Lock Gel tubes (Eppendorf, Germany) were used to facilitate the retrieval of clean DNA during phenol-chloroform extraction. Precipitated DNA was dried in a vacuum centrifuge $\left(20 \mathrm{~min}, 65^{\circ} \mathrm{C}\right)$ to ensure complete phenol removal. Samples were resuspended in $10 \mathrm{mM}$ Tris-HCl, $\mathrm{pH} 7.5$, treated with $1 \mu \mathrm{l}$ DNase-free RNase A $\left(30 \mathrm{~min}, 37^{\circ} \mathrm{C}\right)$ and then with $1 \mu$ l Proteinase $\mathrm{K}(1 \mathrm{~h}$, $\left.56{ }^{\circ} \mathrm{C}\right)$. After overnight incubation $\left(65^{\circ} \mathrm{C}\right)$, the samples were cleaned with DNA Clean \& Concentrator-5 (Zymo Research, USA). DNA from each sample was checked for purity with a NanoDrop ND1000 spectrophotometer (Thermo Fisher Scientific, USA). The size range and concentration of the samples were quantified with the Bioanalyzer 2100 system (Agilent, USA). DNA samples (20 ng in $30 \mu \mathrm{l}$ of nucleasefree water) were sent to Fasteris (Switzerland) for library preparation and sequencing. The libraries were prepared according to ChiP-Seq TruSeq protocol with fragmentation step and sequenced on the Illumina HiSeq 2500 instrument with 150-bp single-end read length.

FAIRE is well suited for finding candidate regulatory regions in poorly annotated complex genomes, e.g., of maize. This method is not biased by chemical DNA fragmentation, which could be problematic in DNase-seq. Additionally, FAIRE, unlike ChIP, does not require high-quality specific antibodies, which are difficult to produce (Tsompana and Buck 2014).

\section{Bioinformatic Analyses}

Sequence reads in fastq format were quality-controlled (FastQC v0.11.2; Andrews 2010) and adapter-cleaned (Trimmomatic v0.36; Bolger et al. 2014). Bowtie2 v2.2.6 (Langmead and Salzberg 2012) was used to map the reads on the B73 AGPv3 reference genome (Schnable et al. 2009). Low-quality alignments $($ score $<10)$ were filtered out with samtools v1.10 (Li et al. 2009). Sequencing data have been deposited in the ArrayExpress database under accession number E-MTAB-8401. The replicates were checked for reproducibility by Spearman correlation and principal component analysis (multiBamSummary, plotCorrelation, and plotPCA commands of deeptools v3.3.1; Ramírez et al. 2016).

Statistically significant open chromatin peaks were detected with the Homer v4.9 package (makeTagDirectory and findPeaks commands; Heinz et al. 2010). Options optimized for finding nucleosome-free regions ("style factor" and "nfr") and 0.05 false discovery rate (FDR) threshold were used. To minimize false positives, we further considered only peaks present in at least two biological replicates of a given variant (temperature $\times$ maize line $\times$ growth stage), as determined by the mergePeaks command of Homer. The peaks were 
annotated relative to gene features (annotatePeaks.pl command of Homer). The $-3 \mathrm{~kb}$ to $+100 \mathrm{bp}$ range around the gene transcription start site (TSS) has been defined here as the "promoter." For peaks located in this region, corresponding gene IDs were retrieved and used in all further functional analyses. The peaks were analyzed for overrepresentation of transcription factor binding sites (TFBSs) using CLOVER (Frith 2004) and a nonredundant set of plant motifs (JASPAR 2014, Mathelier et al. 2014; AthaMap v7, Hehl and Bülow 2014). In the TFBS overrepresentation analysis, three background sequence sets from maize were used: chromosome 10, 26,300 bp upstream gene region, and randomly generated peaks in the $3 \mathrm{~kb}$ upstream gene region. To minimize the number of false positives, only TFBS motifs with score $>0$ and $p$ value $<0.05$ against all three background sets were retained for further analysis, as recommended by CLOVER developers (Frith 2004).

Gene sets with cold-specific NDR in the promoter were retrieved for each line $\times$ growth stage variant. For these gene sets, the protein interaction data were retrieved from the STRING database version 10 (Szklarczyk et al. 2017). Lowconfidence interactions (score $<400$ ) and proteins without interactants were filtered out. Each network was visualized and analyzed with Cytoscape v3.4 (Cline et al. 2007). For functional analyses, the Gene Ontology (GO) annotation of maize genes was used (Wimalanathan et al. 2018). Genes annotated with the "DNA binding transcription factor activity" (GO:0003700) GO term and their interactants were used for enrichment analysis in the BiNGO module of Cytoscape (Maere et al. 2005; Cline et al. 2007). For transcription factors specific for cold treatment in each line $\times$ growth stage variant, we searched for more data. Transcription factors with one of the following GO annotations: "response to cold" (GO:0009409), "response to freezing" (GO:0050826), "response to osmotic stress" (GO:0006970), "response to oxidative stress" (GO:0006979), and "response to salt stress" (GO:0009651), were determined. We also used our microarray results (Sobkowiak et al. 2014, 2016) to check whether transcription factors were previously determined to be differentially expressed in cold-tolerant maize lines. These datasets were overlaid with networks of direct transcription factor interactions. The most connected nodes were detected by hub analysis using the Network Analyzer tool of Cytoscape.

\section{Verification of NDR Peaks and Transcriptional Activation}

Expression of nine selected genes with NDR peak in cold in S68911 plants at V1 stage was validated by RT-qPCR. mRNA was isolated from the first leaf (V1 stage) of coldtreated and control plants with NucleoSpin RNA Plant Kit (Macherey-Nagel, Germany). mRNA was reverse transcribed with the SuperScript First Strand Synthesis System
(Invitrogen, USA). For each gene, reactions for all three biological replicates of each temperature variant were done, each reaction was done in triplicate. Three reference genes were used, ubiquitin (GRMZM2G118637), actin depolymerizing factor (GRMZM2G060702), and synthetic luciferase gene (cat. no. L4561, Promega, USA). Luciferase mRNA (1 ng) was added during the reverse transcription step (O'Shaughnessy et al. 2011). The primers are shown in Online Resource 1 . The results were analyzed with the $\Delta \Delta \mathrm{Ct}$ method (Schmittgen and Livak 2008) using average expression of reference genes. Expression values $(\Delta \mathrm{Ct})$ in cold and control were compared by $t$ test in $\mathrm{R} \mathrm{v3.6.2} \mathrm{(R}$ Development Core Team 2019) with $p$ value cutoff of 0.05 . Reactions were carried out in a CFX96 Touch Real-Time PCR (BioRad, USA) in $10 \mu \mathrm{l}$ volume using $5 \mu \mathrm{l}$ SYBR Green JumpStart Taq ReadyMix (Sigma-Aldrich, USA) with primers at $400 \mathrm{nM}$ each and $2.5 \mu \mathrm{l}$ of 1:50 diluted cDNA. The temperature profile of reactions was as follows: initial denaturation $\left(95^{\circ} \mathrm{C}, 3 \mathrm{~min}\right), 40$ cycles of denaturation $\left(95^{\circ} \mathrm{C}, 5 \mathrm{~s}\right)$, and annealing/extension $\left(60^{\circ} \mathrm{C}, 20 \mathrm{~s}\right)$.

Numerous studies have signified the link between nucleosome-free chromatin in the upstream region of the gene and the activation of gene expression (Hogan et al. 2006; Vera et al. 2014; Rodgers-Melnick et al. 2016; Oka et al. 2017). To complement RT-qPCR verification of our results, we searched public databases, ArrayExpress (Parkinson et al. 2010) and Gene Expression Omnibus (Barrett et al. 2013). Although those databases contain data from numerous studies on maize, most of them are not comparable to our data. For the S68911 line, there are data only from our previous study, which used older plants than those used in this study; therefore, these data could not be used. Our comparison was limited to the B73 line and control conditions due to the lack of the appropriate cold variant in the databases. Coleoptile samples (VE stage) from our study and external studies were compared. From the remaining studies, we selected those in which leaves of approximately 2-week-old (three leaves visible) seedlings were sampled and compared them to V1 stage samples.

Raw data were downloaded from the ArrayExpress database. Fastq files were quality-controlled with FastQC v0.11.9 (Andrews 2010). Adapters and low-quality bases were removed with Trimmomatic v0.39 (Bolger et al. 2014) and only reads at least $40 \mathrm{nt}$ long were kept for further analysis. Reads were mapped to the B73 AGPv3 maize genome with tophat v2.1.1 (Trapnell et al. 2009). In cases when sequencing was done in paired-end mode, only alignments in which both reads in a pair can be mapped were kept ("-no-mixed" option). Low-quality alignments $($ score $<10)$ were filtered-out with samtools v1.10 (Li et al. 2009). Fragments per kilo base per million mapped reads (FPKM) values were computed with cufflinks v2.2.1 (Trapnell et al. 2010). For each compared project genes were divided to two sets, according to presence or absence of NDR peak in promoter region in our results. 
FPKM values for these two sets were compared by t-test in $\mathrm{R}$ v3.6.2 (R Development Core Team 2019). Hypothesis that the true difference in FPKM means is not equal to zero was tested against the null hypothesis of equality of means.

\section{Results}

Two maize inbred lines with contrasting levels of cold sensitivity were compared in this work. Specifically, information on DNA free from nucleosomes in cold-grown seedlings was obtained. Such sequences may contain cis-regulatory elements determining the expression of downstream genes.

On average, the DNA from each experimental variant was sequenced to comparable depth. In the majority of cases, at least two biological replicates showed a high Spearman correlation (Online Resource 2, Fig. 1). The PCA plot shows that major differences between the variants can be attributed to the maize line followed by temperature conditions (Online Resource 2, Fig. 2). More peaks were detected in S68911 than in B73 samples in both control and cold conditions, the basic statistics regarding peak-calling are presented in Online Resource 3. The number of "promoter" peaks in cold conditions relative to the control increased in S68911 (coldtolerant) and decreased in the B73 (cold-sensitive) inbred line along with the growth stage (Online Resource 2, Fig. 3). Example genes with NDR peak in the "promoter" were visualized in genome browser (Online Resource 4, Fig. 4).

\section{Verification of NDR Peaks and Transcriptional Activation}

Expression of nine genes with NDR peak in promoter in S68911 line at V1 stage was checked by the RT-qPCR method. Among chosen genes were those with NDR peak unique to cold and those with NDR peak in both temperature treatments. Expression of six genes was verified successfully. Three genes have NDR peak unique to cold but expression difference between treatments was not statistically significant (Online Resource 1).

To further check the correspondence of NDR presence and transcription of downstream genes, we used public RNA sequencing data. In all comparisons, there was a significantly greater number of reads for genes with NDR peaks in promoters than for genes without NDR peaks. This finding means that genes with NDR were preferentially expressed (Table 1).

\section{Analysis of Regulatory Elements}

Stress can alter the nucleosome occupancy of particular regulatory sequences and induce the expression of a specific set of genes. FAIRE peaks present in the $-3 \mathrm{~kb}$ to $+100 \mathrm{bp}$ region around the TSS of genes (designated the "promoter" region)
Table 1 Correspondence of the presence of the nucleosome-depleted region (NDR) in the gene promoter region and transcriptional activation. The promoter was defined as the $-3 \mathrm{~kb}$ to $+100 \mathrm{bp}$ range around the gene transcription start site. For comparison, the data from the ArrayExpress database were used (Parkinson et al. 2010). A t-test comparing the mean FPKM values for genes with NDR vs. genes without NDR in our study was performed. The results show a significant positive association of NDR presence in the promoter region and expression level of the downstream gene

\begin{tabular}{|c|c|c|c|c|c|}
\hline $\begin{array}{l}\text { Sample } \\
\text { from } \\
\text { this } \\
\text { study }\end{array}$ & $\begin{array}{l}\text { Growth stage } \\
\text { of plants used } \\
\text { in } \\
\text { ArrayExpress } \\
\text { projects }\end{array}$ & $\begin{array}{l}\text { Mean } \\
\text { FPKM } \\
\text { (genes } \\
\text { with } \\
\text { NDR) }\end{array}$ & $\begin{array}{l}\text { Mean } \\
\text { FPKM } \\
\text { (genes } \\
\text { without } \\
\text { NDR) }\end{array}$ & $p$ value & $\begin{array}{l}\text { Project } \\
\text { accession }\end{array}$ \\
\hline $\begin{array}{c}\text { B73 VE } \\
\text { con- } \\
\text { trol }\end{array}$ & $\begin{array}{l}\text { 5-day-old } \\
\text { coleoptile }\end{array}$ & 23 & 16 & $<0.001$ & E-MTAB-3028 \\
\hline $\begin{array}{c}\text { B73 VE } \\
\text { con- } \\
\text { trol }\end{array}$ & Coleoptile & 24 & 16 & $<0.001$ & E-MTAB-4342 \\
\hline $\begin{array}{c}\text { B73 V1 } \\
\text { con- } \\
\text { trol }\end{array}$ & $\begin{array}{l}\text { 12-day-old (3 } \\
\text { leaves } \\
\text { visible) }\end{array}$ & 20 & 15 & 0.04 & E-MTAB-4285 \\
\hline $\begin{array}{c}\text { B73 V1 } \\
\text { con- } \\
\text { trol }\end{array}$ & $\begin{array}{l}\text { 2-week-old } \\
\text { (second } \\
\text { leaf) }\end{array}$ & 22 & 16 & 0.005 & E-MTAB-5063 \\
\hline
\end{tabular}

were analyzed for $c i s$-motif (TFBS) overrepresentation with CLOVER software (Frith 2004). The majority of enriched TFBSs were nonunique for variants (temperature $\times$ maize line $\times$ growth stage). There were no TFBSs enriched specifically in the cold at all developmental stages in one line. However, close to this condition were those for five teosinte branched 1, cycloidea, proliferating cell nuclear antigen factor 1 (TCP) proteins (TCP15, TCP23, OJ1581_H09.2, OsI_08196, and ARALYDRAFT_493022) in S68911 (Table 2(A)). Similarly, in the B73 line, TFBSs for Arabidopsis NAC domain-containing protein 81 (ANAC81), indeterminate growth1 (id1) and TATA-binding protein (TBP) were enriched at all stages (Table 2(B)). During the VE and VE/ V1 stages in the S68911 line, there were many line-specific overrepresented TFBSs targeted by APETALA2/ethyleneresponsive element binding protein (AP2/EREBP) transcription factors (TFs). Such TFBSs were absent at V1 when other motifs were more common (Table 3(A)). Differently in B73, the most numerous TFBSs were targeted by MADS box TFs, which was true for the VE and VE/V1 stages. In this line, only one AP2/EREBP TFBS was enriched at VE/V1 and one at the V1 stage (Table 3(B)). For each overrepresented TFBS, it was determined if its cognate transcription factor had an NDR peak in the same sample. Therefore, transcription factor proteins would potentially be present, and their target genes would be open for regulation. This finding was observed for the S68911 line for auxin response factor 4 (ARF4) and long hypocotyl 5 (HY5) at the VE/V1 stage and for TCP11 at the 
Table 2 Transcription factor binding sites (TFBS) that were significantly enriched among nucleosome-free regions located in gene promoters ( $p$ value $<0.05$, CLOVER program, Frith (2004)) at all stages of development. The results for cold-stressed maize seedlings of line, (A) S68911 (cold-tolerant) and (B) B73 (cold-sensitive). The promoter was defined as the $-3 \mathrm{~kb}$ to $+100 \mathrm{bp}$ region around the gene transcription start site. Growth stages: VE, coleoptile; VE/V1, tip of the second leaf is visible; V1, first leaf fully developed (the collar of the first leaf is visible). C, cold. Change: (+), overrepresentation; (-), underrepresentation; (0), no change. TFBS in italics are annotated as stress-related in the UniProt database

\begin{tabular}{|c|c|c|c|c|c|c|c|c|c|c|c|c|c|c|c|}
\hline \multirow[b]{2}{*}{$\begin{array}{l}\text { Matrix } \\
\text { ID }^{1}\end{array}$} & \multirow[b]{2}{*}{ Name } & \multirow[b]{2}{*}{ TF family ${ }^{2}$} & \multirow[b]{2}{*}{$\begin{array}{l}\text { UniProt } \\
\text { ID }\end{array}$} & \multicolumn{6}{|c|}{ S68911 } & \multicolumn{6}{|l|}{ B73 } \\
\hline & & & & $\mathrm{VE}$ & $\begin{array}{l}\mathrm{VE} / \\
\mathrm{V} 1\end{array}$ & V1 & VE_C & $\begin{array}{l}\text { VE/ } \\
\text { V1_C }\end{array}$ & V1_C & VE & $\begin{array}{l}\mathrm{VE} / \\
\mathrm{V} 1\end{array}$ & V1 & VE_C & $\begin{array}{l}\text { VE/ } \\
\text { V1_C }\end{array}$ & V1_C \\
\hline \multicolumn{16}{|l|}{ (A) } \\
\hline MA0558.1 & FLC & MADS & Q5Q9J1 & 0 & 0 & 0 & + & + & + & 0 & + & 0 & + & + & 0 \\
\hline MA0982.1 & DOF2.4 & $\mathrm{C} 2 \mathrm{H} 2$ & O80928 & 0 & 0 & 0 & + & + & + & 0 & + & 0 & + & + & + \\
\hline MA1001.1 & ERF11 & AP2-EREBP & Q9C5I3 & 0 & 0 & 0 & + & + & + & + & + & 0 & 0 & 0 & + \\
\hline MA1019.1 & Glyma19g26560.1 & TCP & I1N7U7 & 0 & 0 & 0 & + & + & + & + & 0 & + & 0 & 0 & 0 \\
\hline MA1031.1 & OJ1581_H09.2 & TCP & Q6H878 & 0 & 0 & 0 & + & + & + & + & 0 & 0 & 0 & 0 & 0 \\
\hline MA1050.1 & OsI_08196 & TCP & $\mathrm{A} 2 \mathrm{X} 7 \mathrm{~K} 8$ & 0 & 0 & 0 & + & + & + & + & 0 & 0 & 0 & 0 & 0 \\
\hline MA1062.1 & TCР 15 & TCP & Q9C9L2 & 0 & 0 & 0 & + & + & + & + & 0 & 0 & 0 & 0 & 0 \\
\hline MA1064.1 & TCP2 & TCP & Q93V43 & 0 & 0 & 0 & + & + & + & + & 0 & 0 & 0 & 0 & + \\
\hline MA1065.1 & ТCР20 & TCP & Q9LSD5 & 0 & 0 & 0 & + & + & + & + & 0 & + & 0 & 0 & 0 \\
\hline MA1066.1 & TCP23 & TCP & Q9LQF0 & 0 & 0 & 0 & + & + & + & + & 0 & 0 & 0 & 0 & 0 \\
\hline MA1095.1 & $\begin{array}{l}\text { ARALYDRAFT_ }_{495258}\end{array}$ & TCP & D7MRK3 & 0 & 0 & 0 & + & + & + & + & 0 & + & 0 & 0 & 0 \\
\hline MA1097.1 & $\begin{array}{l}\text { ARALYDRAFT_ } \\
493022\end{array}$ & TCP & D7MCT1 & 0 & 0 & 0 & + & + & + & + & 0 & 0 & 0 & 0 & 0 \\
\hline MA1098.1 & $\begin{array}{l}\text { ARALYDRAFT } \\
\quad 484486\end{array}$ & TCP & D7LRC3 & 0 & 0 & 0 & + & + & + & + & 0 & + & 0 & 0 & 0 \\
\hline \multicolumn{16}{|c|}{ 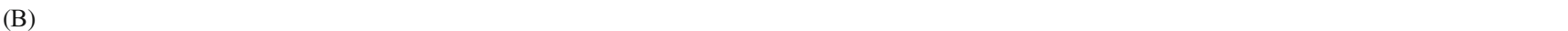 } \\
\hline & $\begin{array}{l}\text { ANAC81 } \\
\text { AtMYB61 }\end{array}$ & $\begin{array}{l}\text { NAC } \\
\text { MYB }\end{array}$ & $\begin{array}{l}\text { Q9C598 } \\
\text { Q8VZQ2 }\end{array}$ & $\begin{array}{l}0 \\
+\end{array}$ & $\begin{array}{l}0 \\
0\end{array}$ & $\begin{array}{l}0 \\
0\end{array}$ & $\begin{array}{l}0 \\
+\end{array}$ & $\begin{array}{l}0 \\
+\end{array}$ & $\begin{array}{l}0 \\
0\end{array}$ & $\begin{array}{l}0 \\
+\end{array}$ & $\begin{array}{l}+ \\
+\end{array}$ & $\begin{array}{l}0 \\
0\end{array}$ & $\begin{array}{l}+ \\
+\end{array}$ & $\begin{array}{l}+ \\
+\end{array}$ & $\begin{array}{l}+ \\
+\end{array}$ \\
\hline & GAMYB & MYB & & + & + & 0 & + & + & + & + & + & 0 & + & + & + \\
\hline MA0034.1 & Gam1 & MYB & Q96464 & + & + & 0 & + & + & + & + & + & 0 & + & + & + \\
\hline MA0120.1 & id1 & $\mathrm{C} 2 \mathrm{H} 2$ & O65215 & + & 0 & 0 & 0 & 0 & 0 & 0 & + & 0 & + & + & + \\
\hline MA0128.1 & EmBP-1 & bZIP & P25032 & + & 0 & 0 & + & + & 0 & + & + & 0 & + & + & + \\
\hline MA0570.1 & $\mathrm{ABF} 1$ & bZIP & Q9M7Q5 & + & 0 & 0 & + & + & 0 & 0 & 0 & - & + & + & + \\
\hline MA0968.1 & bZIP68 & bZIP & Q84LG2 & + & 0 & 0 & + & + & + & + & 0 & 0 & + & + & + \\
\hline MA0981.1 & DOF1.8 & $\mathrm{C} 2 \mathrm{H} 2$ & Q84JQ8 & 0 & 0 & 0 & + & + & 0 & 0 & + & 0 & + & + & + \\
\hline MA0982.1 & DOF2.4 & $\mathrm{C} 2 \mathrm{H} 2$ & O80928 & 0 & 0 & 0 & + & + & + & 0 & + & 0 & + & + & + \\
\hline MA0983.1 & DOF5.6 & $\mathrm{C} 2 \mathrm{H} 2$ & Q9FM03 & 0 & 0 & - & + & + & 0 & 0 & + & 0 & + & + & + \\
\hline MA0987.1 & $\begin{array}{l}\text { PHYPADRAFT }_{-} \\
140773\end{array}$ & $\mathrm{C} 2 \mathrm{H} 2$ & A9T5V8 & + & 0 & 0 & + & + & 0 & 0 & + & 0 & + & + & + \\
\hline MA0990.1 & EDT1 & Homeobox & Q9FX31 & 0 & 0 & 0 & + & 0 & 0 & - & + & - & + & + & + \\
\hline MA1022.1 & $\begin{array}{l}\text { PHYPADRAFT }_{-} \\
38837\end{array}$ & $\mathrm{C} 2 \mathrm{H} 2$ & A9TZG0 & 0 & 0 & 0 & + & + & 0 & 0 & + & 0 & + & + & + \\
\hline MA1037.1 & MYB24 & MYB & Q9SPG9 & 0 & 0 & 0 & + & + & 0 & + & 0 & 0 & + & + & + \\
\hline \multirow{2}{*}{ MA1071.1 } & DOF5.3 & $\mathrm{C} 2 \mathrm{H} 2$ & Q84TE9 & + & 0 & 0 & + & + & + & 0 & + & 0 & + & + & + \\
\hline & TBP & & & + & 0 & 0 & 0 & 0 & 0 & 0 & + & 0 & + & + & + \\
\hline
\end{tabular}

${ }^{1}$ Matrix IDs and names after JASPAR 2014 (MA prefix) (Mathelier et al. 2014) and AthaMap (Hehl and Bülow 2014)

${ }^{2}$ TF families after grassius (Yilmaz et al. 2009)

V1 stage. In the B73 line, the above criterion fulfilled HY5 at the V1 stage. Details on the TFBS enrichment analysis are given in Online Resource 5.

\section{Transcription-Factor Level Analyses}

For each variant (line $\times$ growth stage), a set of genes with cold-specific NDRs was defined. For these sets, protein interaction networks (STRING v10; Szklarczyk et al. 2017) have been created. These networks were used in enrichment analysis in the BiNGO module of Cytoscape (Maere et al. 2005; Cline et al. 2007). This analysis aimed to identify functional categories overrepresented among proteins directly interacting with transcription factors (sample set) against all proteins in a given network (population set). Transcription factors were selected based on the "DNA binding transcription factor activity" (GO:0003700) GO annotation (Wimalanathan et al. 2018). Categories from the Biological Process GO class were analyzed. For the S68911 line, both negative and positive regulation of gene expression was observed, which was 
Table 3 Transcription factor binding sites (TFBS) that were significantly enriched among nucleosome-free regions located in the promoter region of genes. The results for cold-stressed maize seedlings of line, (A) S68911 (cold-tolerant), (B) B73 (cold-sensitive). Only TFBS specific for one or two consecutive growth stages in a given line in cold are shown. Further description is provided in Table 1

\begin{tabular}{|c|c|c|c|c|c|c|c|c|c|c|c|c|}
\hline \multirow[b]{2}{*}{ TFBS ID $^{1}$} & \multirow[b]{2}{*}{ TF family ${ }^{2}$} & \multicolumn{6}{|c|}{ S68911 } & \multicolumn{5}{|c|}{ B73 } \\
\hline & & VE & $\begin{array}{l}\mathrm{VE} / \\
\mathrm{V} 1\end{array}$ & V1 & VE_C & $\begin{array}{l}\mathrm{VE} / \\
\mathrm{V} 1 \mathrm{C}\end{array}$ & V1_C & $\mathrm{VE}$ & $\begin{array}{l}\text { VE/ } \\
\text { V1 }\end{array}$ & V1 VE_C & $\begin{array}{l}\mathrm{VE} / \\
\mathrm{V} 1 \mathrm{C}\end{array}$ & V1_C \\
\hline
\end{tabular}

(A)

\begin{tabular}{|c|c|c|c|c|c|c|c|c|c|c|c|c|c|c|c|}
\hline \multirow[t]{2}{*}{ MA0984.1 } & DOF5.7 & $\mathrm{C} 2 \mathrm{H} 2$ & Q9LSL6 & 0 & 0 & 0 & + & 0 & 0 & 0 & 0 & 0 & 0 & 0 & 0 \\
\hline & AHL12(2) & AT-hook & Q8LPN5 & 0 & 0 & 0 & + & 0 & 0 & 0 & 0 & 0 & 0 & 0 & 0 \\
\hline MA0567.1 & $E R F 1 B$ & AP2-EREBP & Q8LDC8 & 0 & 0 & 0 & + & + & 0 & 0 & 0 & 0 & 0 & 0 & 0 \\
\hline MA0980.1 & $R A P 2-10$ & AP2-EREBP & Q9SW63 & 0 & 0 & 0 & + & + & 0 & 0 & 0 & 0 & 0 & 0 & 0 \\
\hline MA1005.1 & $E R F 3$ & AP2-EREBP & O80339 & 0 & 0 & 0 & + & + & 0 & 0 & 0 & 0 & 0 & 0 & 0 \\
\hline MA1034.1 & Os05g0497200 & AP2-EREBP & Q75K84 & 0 & 0 & 0 & + & + & 0 & 0 & 0 & 0 & 0 & 0 & 0 \\
\hline MA0951.1 & ATHB-16 & Homeobox & Q940J1 & 0 & 0 & 0 & 0 & + & 0 & 0 & 0 & 0 & 0 & 0 & 0 \\
\hline MA0974.1 & CDF3 & $\mathrm{C} 2 \mathrm{H} 2$ & Q8LFV3 & 0 & 0 & 0 & 0 & + & 0 & 0 & 0 & 0 & 0 & 0 & 0 \\
\hline MA0975.1 & $C R F 2$ & AP2-EREBP & Q9SUQ2 & 0 & 0 & 0 & 0 & + & 0 & 0 & 0 & 0 & 0 & 0 & 0 \\
\hline MA0976.1 & CRF4 & AP2-EREBP & Q9SUE3 & 0 & 0 & 0 & 0 & + & 0 & 0 & 0 & 0 & 0 & 0 & 0 \\
\hline MA0992.1 & ERF4 & AP2-EREBP & O80340 & 0 & 0 & 0 & 0 & + & 0 & 0 & 0 & 0 & 0 & 0 & 0 \\
\hline MA1015.1 & GATA12 & C2C2-GATA & P69781 & 0 & 0 & 0 & 0 & + & 0 & - & 0 & 0 & 0 & 0 & 0 \\
\hline MA1048.1 & ERF018 & AP2-EREBP & Q9S7L5 & 0 & 0 & 0 & 0 & + & 0 & 0 & 0 & 0 & 0 & 0 & 0 \\
\hline MA1051.1 & $R A P 2-3$ & AP2-EREBP & P42736 & 0 & 0 & 0 & 0 & + & 0 & 0 & 0 & 0 & 0 & 0 & 0 \\
\hline MA1052.1 & $R A P 2-6$ & AP2-EREBP & Q7G1L2 & 0 & 0 & 0 & 0 & + & 0 & 0 & 0 & 0 & 0 & 0 & 0 \\
\hline \multirow[t]{2}{*}{ MA1053.1 } & ERF109 & AP2-EREBP & Q9SZ06 & 0 & 0 & 0 & 0 & + & 0 & 0 & 0 & 0 & 0 & 0 & 0 \\
\hline & YAB1 & C2C2-YABBY & O22152 & 0 & 0 & 0 & 0 & + & + & 0 & 0 & 0 & 0 & 0 & 0 \\
\hline \multirow[t]{4}{*}{ MA0565.1 } & FUS3 & ABI3-VP1 & Q9LW31 & 0 & 0 & 0 & 0 & 0 & + & 0 & 0 & 0 & 0 & 0 & 0 \\
\hline & RVE1(1) & MYB & F4KGY6 & 0 & 0 & 0 & 0 & 0 & + & 0 & 0 & 0 & 0 & 0 & 0 \\
\hline & STY1(2) & SHI/STY (SRS) & Q9SD40 & 0 & 0 & 0 & 0 & 0 & + & 0 & 0 & 0 & 0 & 0 & 0 \\
\hline & ZAT2 & $\mathrm{C} 2 \mathrm{H} 2$ & Q9SIJ0 & 0 & 0 & 0 & 0 & 0 & + & 0 & 0 & 0 & 0 & - & 0 \\
\hline \multicolumn{16}{|l|}{ (B) } \\
\hline MA0008.2 & HAT5 & Homeobox & Q02283 & 0 & 0 & 0 & 0 & 0 & 0 & 0 & 0 & 0 & + & 0 & 0 \\
\hline MA0940.1 & AP1 & MADS & P35631 & 0 & 0 & 0 & 0 & 0 & 0 & 0 & 0 & 0 & + & + & 0 \\
\hline MA0563.1 & SEP3 & MADS & O22456 & 0 & 0 & 0 & 0 & 0 & 0 & 0 & 0 & 0 & + & + & 0 \\
\hline MA0082.1 & squamosa & MADS & Q38742 & 0 & 0 & 0 & 0 & 0 & 0 & 0 & 0 & 0 & + & + & 0 \\
\hline MA0559.1 & PI & MADS & P48007 & 0 & 0 & 0 & 0 & 0 & 0 & 0 & 0 & 0 & 0 & + & 0 \\
\hline \multirow[t]{2}{*}{ MA0584.1 } & SEP1 & MADS & P29382 & 0 & 0 & 0 & 0 & 0 & 0 & 0 & 0 & 0 & 0 & + & 0 \\
\hline & WRII & AP2-EREBP & Q6X5Y6 & 0 & 0 & 0 & 0 & 0 & 0 & 0 & 0 & 0 & 0 & + & 0 \\
\hline MA0998.1 & ERF096 & AP2-EREBP & Q9LSX0 & 0 & 0 & 0 & 0 & 0 & 0 & 0 & 0 & 0 & 0 & 0 & + \\
\hline MA1028.1 & KAN4 & G2-like & Q9FJV5 & 0 & 0 & 0 & 0 & 0 & 0 & 0 & 0 & 0 & 0 & 0 & + \\
\hline
\end{tabular}

${ }^{1}$ Matrix IDs and names after JASPAR 2014 (MA prefix) (Mathelier et al. 2014) and AthaMap (Hehl et al. 2014)

${ }^{2} \mathrm{TF}$ families after grassius (Yilmaz et al. 2009)

connected with chromatin changes ("chromatin silencing"). Categories related to development were enriched at the VE ("cell differentiation") and VE/V1 ("developmental process") stages. Categories related to stress were shifted forward; at VE/V1, it was "immune system process", whereas at V1, it was "response to stress" and "DNA repair" (Online Resource 6). For the B73 line, there was an enrichment for the V1 sample only. In this line, the most characteristic overrepresented categories were related to gene expression and DNA repair (Online Resource 6).

The network of transcription factors for the S68911 line was larger at later stages than at VE. For this line, there were three transcription factors common to all cold variants: knotted 1 (KN1), wuschel 1 (WUS1), and GATA zinc finger family protein 17 (GATA17). In the S68911 line, GATA17 was a highly connected node at all stages, and it was the hub at the 
VE stage. At this stage, there were two transcription factors described in the literature (Bolduc et al. 2012), but not in STRING, as interacting with KN1. This finding was observed for the DELLA protein Dwarf plant 9 (D9) and the Homeobox transcription factor 102 (HB102) (Fig. 1).

The network for the VE/V1 stage for the S68911 line contained few highly connected hubs, and the main hub was histone-lysine N-methyltransferase (SUVR5). This gene interacted with HY5, whose TFBS was enriched at this developmental stage. HY5 was itself connected with four heat shock transcription factors (HSFs). SUVR5 also interacted with several epigenetic and MYB proteins, and it was connected with the second hub, GATA17, interacting with MADS proteins. WUS1 interacted with ARF4, whose TFBS was enriched at this stage (Fig. 2a).

The main hub of the V1 network for the S68911 line was GATA34. This gene interacted with two hubs, GATA17 and the two-component response regulator ARR12. Directly and via three MYB factors, the central hub interacted with the basic region/leucine zipper (BZIP122). The latter was connected itself with several HSFs, some shared with the VE/ V1 stage. GATA34 also interacted with several developmental (MADS and homeotic) transcription factors. As at other growth stages, at V1, there was a subnetwork containing mainly homeotic proteins centered around KN1 and WUS1; however, at each stage, the composition of the subnetwork varied. At the V1 stage, there was also a second small network of three AP2-EREBP proteins joined by interaction with WRKY108 (Fig. 2b).

For the B73 maize line, there was a network of transcription factors for the V1 stage only. The central protein was transcription factor HY5 connected with nine other proteins which, in most cases, did not have further connections.

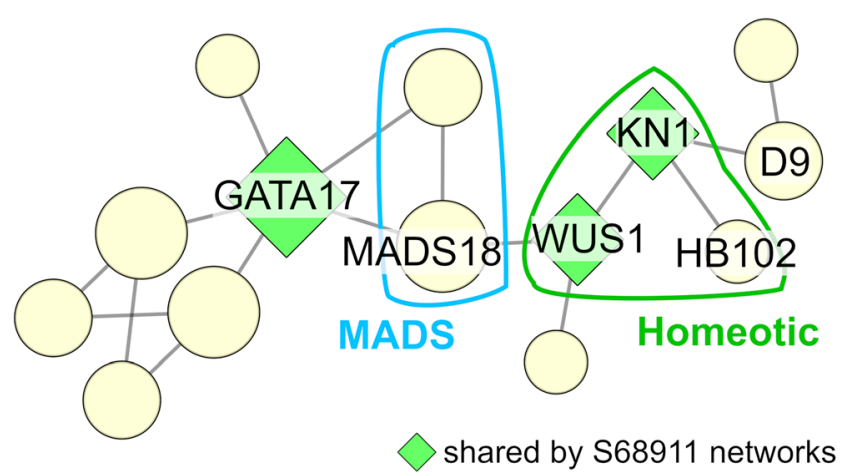

Fig. 1 Network of transcription factors potentially upregulated in S68911 maize seedlings at the VE stage in cold conditions. Genes discussed in the article text and some connecting them are labeled. Closely connected members of some transcription-factor families or functional groups are outlined in color. KN1 was shared by all S68911 networks and upregulated in transcriptomic studies. Abbreviations: D9, Dwarf plant 9; GATA17, GATA zinc finger family protein 17; HB102, Homeoboxtranscription factor 102; KN1, knotted 1; WUS1, wuschel 1; MADS18, Zea mays MADS18
Among the proteins interacting with HY5 were three HSFs (Fig. 3). TFBS for HY5 was enriched at this developmental stage.

In summary, the investigated maize lines differed markedly at the level of potentially activated transcription factors. Nonetheless, the shared element was HY5, and its TFBS was enriched in both lines, although earlier in S68911 (at VE/V1 stage) than in B73 (at V1 stage). Network files are available in Online Resource 7.

\section{Discussion}

Maize exhibits a high level of diversity at both the phenotypic and genomic levels. Variability in cold sensitivity has enabled the successful cultivation of maize in the temperate climate. Although it was possible due to breeding relying on trial and error, as the molecular level causes of lower cold sensitivity of some maize lines are unknown.

In this work, the reaction of the first maize leaf to cold at the, especially poorly known, chromatin level was assessed. Specifically, potentially expressed genes and cis-regulatory motifs accessible for transcription factors were analyzed. DNA free of nucleosomes was isolated and sequenced. Three early growth stages of two inbred lines, cold-tolerant S68911 and cold-sensitive B73, were investigated.

\section{Verification of NDR Peaks and Transcriptional Activation}

In RT-qPCR reactions, upregulation of all nine genes in cold relative to control was observed. However, not always the expression change was statistically significant ( $t$ test, $p<0.05)$. Comparing the qPCR and FAIRE-seq results, four cases could be distinguished: (1) clearly verified genes with stronger expression in cold and NDR peak unique for cold; (2) genes with stronger expression in cold but NDR peak in both cold and control, what could take place, when in cold also other factors positively regulate expression of gene; (3) clearly verified genes with nonsignificant expression difference in cold and control and NDR peak in both conditions; (4) unverified genes without significant expression difference between treatments but with NDR peak unique for cold. Taken together, FAIRE-seq and RT-qPCR results are in good correspondence. It is supported by the good correspondence of FAIRE-seq results and RNA-seq expression data from the ArrayExpress database (Table 1). Nevertheless, the differences for some genes mean that FAIRE-seq and other chromatin-level methods need verification by expression assays. 

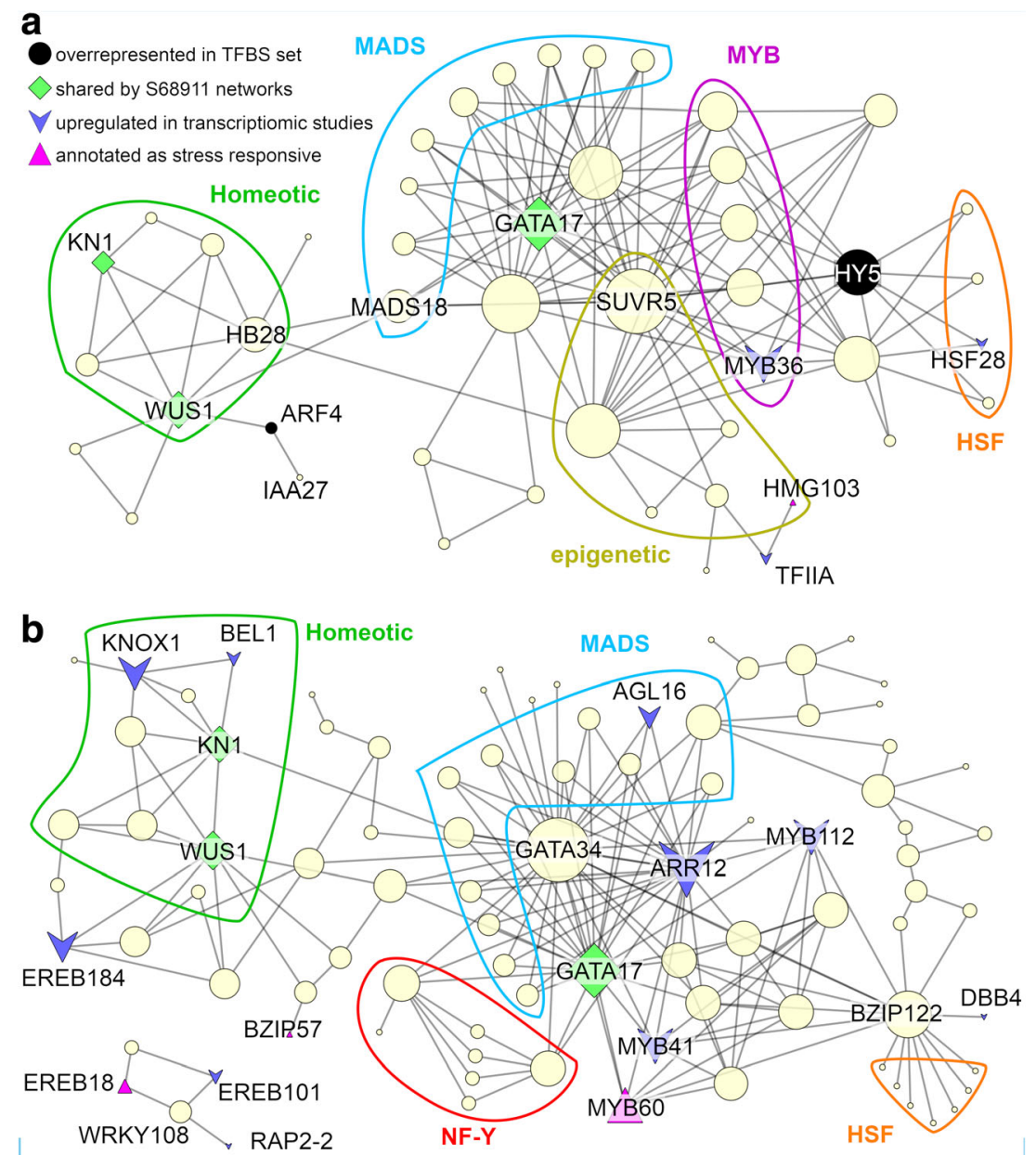

Fig. 2 Network of transcription factors potentially upregulated in S68911 maize seedlings at the a VE/V1 and b V1 stages in cold conditions. Genes discussed in the article text and some connecting them are labeled. Closely connected members of some transcription-factor families or functional groups are outlined in color. KN1 was shared by all S68911 networks and upregulated in transcriptomic studies. Abbreviations: AGL16, agamous-like protein 16; ARF4, auxin response factor 4; ARR12, two-component response regulator ARR12; BEL1, BEL1-like homeodomain protein 3; BZIP57, transcription factor PERIANTHIA; BZIP122, bZIP transcription factor superfamily protein 122; DBB4, Bbox zinc finger protein 24; EREB18, AP2 domain-containing protein 18; EREB101, ethylene-responsive transcription factor ERF055; EREB184,

\section{Cold-Stressed Plants of the Cold-Tolerant Line Adapt the Photosynthetic Apparatus to Cold and Activate Antioxidative Systems}

Potential metabolic-level differences between the S68911 and B73 maize lines were analyzed using the CornCyc database version 7 (Walsh et al. 2016). Potentially activated reactions in each pathway were counted for each experimental variant. This procedure has defined pathways that showed consistent changes in cold-treated vs. control plants in subsequent developmental stages. Among the pathway categories potentially upregulated in the cold-tolerant line grown in the cold, the most numerous were as follows: secondary metabolism, fatty
AP2-like ethylene-responsive transcription factor ANT; GATA34, GATA zinc finger family protein 34 ; HB28, pathogenesis-related homeodomain protein; HMG103, high mobility group B protein 2; HSF28, HSF type transcription factor 28; HY5, long hypocotyl 5; IAA27, auxin-responsive protein IAA27; KN1, knotted 1; KNOX1, knotted related homeobox1; MADS18, Zea mays MADS18; MYB36, myb domain protein 109; MYB41, R2R3MYB-domain protein 41; MYB60, myb domain protein 60; MYB112, myb domain protein 112; RAP2-2, ethylene-responsive transcription factor RAP2-2; SUVR5, histone-lysine N-methyltransferase SUVR5; TFIIA, transcription factor IIA alpha/beta subunit; WRKY108, probable WRKY transcription factor 75; WUS1, wuschel 1

acid biosynthesis, cofactor biosynthesis, reactive oxygen species (ROS) scavenging, and hormone biosynthesis (Online Resources 8 and 9).

Photosynthesis was one of the processes activated in the cold-tolerant S68911 line during cold stress (Online Resource 8). In a previous study, several maize lines were compared under the same growth and stressful temperature conditions used in this work. That study showed that the photosynthetic apparatus of the first leaf was significantly more efficient in S68911 than in B73 and other cold-sensitive maize lines (Grzybowski et al. 2019). Additionally, S68911 seedlings at the V3 stage acclimate to severe cold $\left(<8{ }^{\circ} \mathrm{C}\right)$ during growth in the short-term moderate cold $\left(10-14{ }^{\circ} \mathrm{C}\right)$ and successfully 


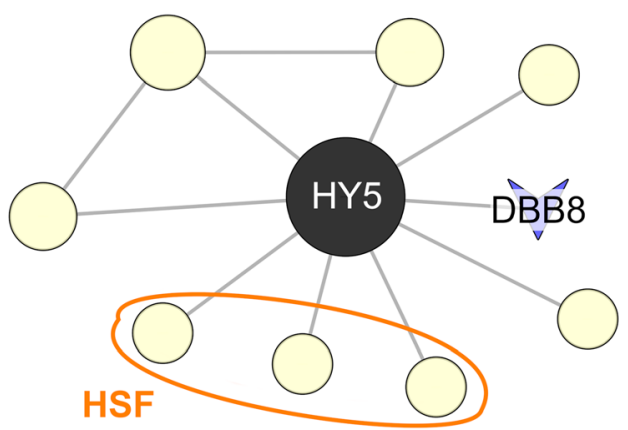

$\checkmark$ upregulated in transcriptomic studies

overrepresented in TFBS set

Fig. 3 Network of transcription factors potentially upregulated in B73 maize seedlings at the V1 stage in cold conditions. Genes discussed in the article text and some connecting them are labeled. Closely connected members of some transcription-factor families or functional groups are outlined in color. Abbreviations: DBB8, B-box zinc finger protein 22; HSFs, heat-shock transcription-factors; HY5, long hypocotyl 5

recover when stress ceases (Sobkowiak et al. 2016). Acclimation was shown by, among others, a photosynthetic apparatus, relatively efficient in S68911 in comparison to the cold-sensitive lines (Sobkowiak et al. 2016). Similar results were obtained for four cold-tolerant maize lines grown in cold (Verheul et al. 1996; Haldimann 1999). The positive cold response of photosynthesis-related genes in S68911 and other cold-tolerant lines is notable. Photosynthesis is regarded as the most cold-sensitive process in maize (Kingston-Smith and Foyer 2000; Sobkowiak et al. 2014) and in C4 plants in general (Long 1983).

During cold stress, the dark phase of photosynthesis is disturbed earlier, and the light phase is overexcited, generating ROS and leading to photoinhibition (Lidon et al. 2001). One of the causes is a decrease in enzymatic reaction velocity, importantly antioxidative reactions (Leipner and Stamp 2009). This decrease is stronger in C4 plants, such as maize, in which elements of photosynthetic and antioxidative systems are separated into two cell types, and transport of intermediates between them must be operational (Foyer et al. 2002). It has been shown that both short- and long-distance transport is impaired in cold-stressed maize seedlings (Sowiński et al. 2003; Bilska-Kos et al. 2016). As we have found, among the potentially activated pathways in S68911 were those related to ROS. Two of these pathways are located in chloroplasts, "detoxification of reactive carbonyls in chloroplasts" and "zeaxanthin, antheraxanthin, and violaxanthin interconversion." The former is potentially activated in S68911 at all growth stages investigated in this work. Increased activity of the antioxidative system components was shown previously in cold-tolerant maize lines under cold conditions (Hodges et al. 1997; Aroca et al. 2001). Similarly, cold-tolerant $Z$. diploperennis showed higher activity of antioxidative enzymes than $Z$. mays (Jahnke et al. 1991).

\section{The Cold-Tolerant Maize Line Activates Stress- Response Processes to Survive Low-Temperature Conditions}

Three cold signaling systems are known in plants: inducer of $\mathrm{CBF}$ expression-C-repeat binding factor/dehydration responsive element binding (ICE-DREB/CBF), abscisic acid (ABA)-dependent, and mitogen-activated protein kinase (MAPK) cascade (Buti et al. 2018). Many components of these pathways were potentially expressed in S68911, mostly at the VE/V1 and V1 stages (Tables 4 and 5). Buti et al. (2018) postulated that the ICE-CBF/DREB pathway accounts for the difference in cold tolerance between two rice varieties. There was virtually no activation of cold signaling pathways in the B73 line.

Several TFBSs targeted by AP2/EREBP cold-responsive transcription factors were overrepresented in S68911 seedlings grown in cold conditions (Table 3(A)). Members of this family were also present in the interaction network for the V1 stage (Fig. 2b). These findings agree with the high expression of EREB101 and related to apetala 2-2 (RAP2-2) in S68911 in the cold (Sobkowiak et al. 2016). Similar response was found for EREB101 in the cold-tolerant ETH-DH7 maize line (Sobkowiak et al. 2014). The expression level of RAP2-2 was positively related to the freezing tolerance of the two maize lines ( $\mathrm{Li}$ et al. 2016). In the B73 line, only two AP2/EREBP cis-elements were enriched (Table 3(B)). This fact could indicate delayed and weaker activation of stress-responsive genes in the B73 line.

Other stress-responsive factors, HSFs, were present in the networks for the VE/V1 and V1 stages in the S68911 line (Fig. 2). HSF28 was present in the VE/V1 network in the cold. Expression of this gene was positively related to the cold tolerance level of three maize lines, reaching a maximal value in S68911 (Sobkowiak et al. 2016).

\section{Hormone-Level Changes and Defense Mode in the Cold-Tolerant Line}

Marked morphological differences were observed between S68911 and B73 maize seedlings grown under cold conditions (Grzybowski et al. 2019 and this study). This fact prompted us to perform a detailed analysis of potential regulation at the hormone level in cold-stressed maize. The analysis of CornCyc pathways showed that in the S68911 line in the cold conditions the most dynamic changes concerned the metabolism of gibberellins (GAs) with both their inactivation and synthesis. As for stress-related hormones, ABA was synthesized at all stages investigated, and jasmonic acid (JA) was synthesized at the VE/V1 and V1 stages (Online Resource 8). To complement the analysis of CornCyc pathways, which do not comprise hormone signaling, the Plant Reactome database release 15 (Naithani et al. 2017) was used. In a number of 
Table 4 Known cold-responsive genes that were potentially upregulated in this study. S68911, cold-tolerant line; B73, coldsensitive line. Growth stages: VE, coleoptile; VE/V1, tip of the second leaf is visible; V1, first leaf is fully developed (the collar of the first leaf is visible). C, cold. Change: (+), upregulation; (0), no upregulation

\begin{tabular}{|c|c|c|c|c|c|c|c|c|}
\hline \multirow[b]{2}{*}{ Gene ID } & \multirow[b]{2}{*}{ Gene name } & \multirow[b]{2}{*}{ Reference } & \multicolumn{3}{|c|}{ S68911 } & \multicolumn{3}{|l|}{ B73 } \\
\hline & & & VE_C & $\begin{array}{l}\text { VE/ } \\
\text { V1_C }\end{array}$ & V1_C & VE_C & $\begin{array}{l}\text { VE/ } \\
\text { V1_C }\end{array}$ & V1_C \\
\hline GRMZM2G006745 & Ereb22 & Liu et al. 2013 & + & 0 & 0 & 0 & 0 & 0 \\
\hline GRMZM2G061487 & Dbf1 & UniProtKB - Q8LKW9 & + & 0 & 0 & 0 & 0 & 0 \\
\hline GRMZM2G070111 & CBF1 & UniProtKB - B6TAF3 & + & 0 & 0 & 0 & 0 & 0 \\
\hline GRMZM2G174917 & Ereb47 & UniProtKB - C0PPB1 & 0 & + & 0 & 0 & 0 & 0 \\
\hline GRMZM2G323172 & Ereb9 & Liu et al. 2013 & 0 & + & 0 & 0 & 0 & 0 \\
\hline GRMZM2G080912 & CIR & UniProtKB - C0PH10 & 0 & + & 0 & + & 0 & 0 \\
\hline GRMZM2G376255 & Ereb48 & Liu et al. 2013 & 0 & + & + & 0 & 0 & 0 \\
\hline GRMZM2G055204 & Ereb18 & Wang et al. 2011 & 0 & 0 & + & 0 & 0 & 0 \\
\hline GRMZM2G124011 & Ereb65 & Liu et al. 2013 & 0 & 0 & + & 0 & 0 & 0 \\
\hline GRMZM2G156737 & Ereb89 & Liu et al. 2013 & 0 & 0 & + & 0 & 0 & 0 \\
\hline GRMZM2G172936 & Ereb6 & UniProtKB - B6TJZ1 & 0 & 0 & + & 0 & 0 & 0 \\
\hline GRMZM2G399098 & Ereb124 & Liu et al. 2013 & 0 & 0 & + & 0 & 0 & 0 \\
\hline GRMZM2G421033 & Ereb156 & UniProtKB - C0P4V5 & 0 & 0 & + & 0 & 0 & 0 \\
\hline
\end{tabular}

Table 5 Maize homologs of cold-response elements described in rice (Buti et al. 2018), potentially upregulated in cold. (A) ICE-CBF/DREB coldsignaling pathway, (B) MAPK-cascade, (C) ABA-dependent pathway. S68911, cold-tolerant line; B73, cold-sensitive line. Abbreviations as in Table 4

\begin{tabular}{|c|c|c|c|c|c|c|c|c|}
\hline \multirow[b]{2}{*}{ Rice gene name } & \multirow[b]{2}{*}{ Gene ID } & \multirow[b]{2}{*}{ Gene name } & \multicolumn{3}{|c|}{ S68911 } & \multicolumn{3}{|l|}{ B73 } \\
\hline & & & VE_C & $\begin{array}{l}\text { VE/ } \\
\text { V1_C }\end{array}$ & V1_C & VE_C & $\begin{array}{l}\text { VE/ } \\
\text { V1_C }\end{array}$ & V1_C \\
\hline
\end{tabular}

(A)

\begin{tabular}{|c|c|c|c|c|c|c|c|c|}
\hline OsCDPK7 & GRMZM2G314396 & ZmCDPK1 & 0 & 0 & + & 0 & 0 & 0 \\
\hline OsCDPK7 & GRMZM2G321239 & CDPK4 & 0 & + & + & 0 & 0 & 0 \\
\hline OsCDPK21 & GRMZM2G332660 & Putative CDPK & 0 & + & 0 & 0 & 0 & 0 \\
\hline OsMYB2 & GRMZM2G134279 & myb29 & 0 & 0 & + & 0 & 0 & 0 \\
\hline OsMYB2 & GRMZM2G070849 & myb75 & 0 & 0 & 0 & 0 & 0 & + \\
\hline OsMYB53 & GRMZM5G813892 & mybr43 & 0 & + & + & 0 & 0 & 0 \\
\hline OsMYB53 & GRMZM2G034110 & mybr31 & 0 & 0 & + & 0 & 0 & 0 \\
\hline \multicolumn{9}{|l|}{ (B) } \\
\hline OsMKK6 & GRMZM2G167856 & ZmMEK1 & 0 & + & 0 & 0 & 0 & 0 \\
\hline OsMPK6 & GRMZM2G127141 & Simk1 & + & + & 0 & 0 & 0 & 0 \\
\hline OsMYB4 & GRMZM2G395672 & myb10 & 0 & + & 0 & + & 0 & 0 \\
\hline OsTRX23 & GRMZM2G082886 & Thioredoxin & 0 & + & 0 & 0 & 0 & 0 \\
\hline \multicolumn{9}{|l|}{ (C) } \\
\hline OsABF3 & GRMZM2G033413 & bzip100 & 0 & + & 0 & 0 & 0 & 0 \\
\hline OsABF3 & GRMZM2G008166 & bzip125 & 0 & + & + & 0 & 0 & 0 \\
\hline OsABF1 & GRMZM2G438293 & bzip44 & 0 & + & + & 0 & 0 & 0 \\
\hline OsABF2 & GRMZM2G479760 & bzip4 & + & 0 & 0 & 0 & 0 & 0 \\
\hline OsABF5 & GRMZM2G157722 & bzip68 & 0 & 0 & + & 0 & 0 & 0 \\
\hline OsNAC4 & GRMZM2G068973 & $\operatorname{nac} 23$ & 0 & 0 & + & 0 & 0 & 0 \\
\hline OsNAC6 & GRMZM2G014653 & nac109 & 0 & 0 & 0 & + & 0 & 0 \\
\hline OsNAC5 & GRMZM2G123667 & nac125 & + & + & 0 & 0 & 0 & 0 \\
\hline
\end{tabular}


cases, a single reaction in the pathway could be performed by more than one gene product. To account for this fact, a set of genes responsible for a single reaction is collectively referred to as a "node." For each node in each signaling pathway, the number of genes with NDR peaks in the promoter was counted (Online Resource 10).

GA and JA signaling are mutually antagonistic by the action of DELLA proteins. The balance of these hormones determines defense or growth response (Colebrook et al. 2014). The potential prevalence of expression of JA synthesis genes (Online Resource 8) and JA signaling over GA signaling (Online Resource 10) observed in S68911 seedlings suggests their switching to defense mode (Borrego and Kolomiets 2016). A similar reaction has not been observed in B73. Stresses that slow the metabolism, including cold, cause degradation of active GAs. It was postulated that this degradation helps the plant survive (Shan et al. 2013; Colebrook et al. 2014). It was shown that $S 68911$ seedlings were not sensitive to externally applied GA3, what was measured as mesocotyl length. Conversely, GA3 had significant positive effect on B73 seedlings. (Grzybowski et al. 2019). Nevertheless, coldstressed sensitive and tolerant seedlings of rice showed negative and positive GA response, respectively (Buti et al. 2018). The JA-deficient opr7opr8 maize double mutant has longer mesocotyl and coleoptile (Yan et al. 2014). This observation links JA and the xeromorphic phenotype observed in cold stress in S68911 and other cold-tolerant maize lines (Verheul et al. 1996; Sowiński et al. 2003; Strigens et al. 2013; Grzybowski et al. 2019).

Potential activation of JA synthesis and signaling in the S68911 line is in keeping with research on cold-stressed $O$. sativa (Du et al. 2013). This hormone upregulated the ICE-CBF/DREB cold signaling pathway (Hu et al. 2013). JA increased the cold tolerance of rice seedlings (Lee et al. 1996), and more tolerant lines had an elevated level of this hormone (Buti et al. 2018). JA and cold stress are linked by the chloroplast membrane, which is a site of both JA synthesis and cold reception (Chinnusamy et al. 2007; Borrego and Kolomiets 2016).

$\mathrm{JA}$ and ABA synthesis genes were potentially expressed in cold in the cold-tolerant line. It was shown that both hormones induce JA-synthesizing genes (Zhang et al. 2005). Additionally, the ABA-dependent cold signaling pathway is potentially activated, as also have been shown by Zhao et al. (2015). ABA is critical in the maintenance of water relations in maize (Zhang et al. 2012). The level of this hormone increased in maize lines grown in the cold, regardless of their tolerance level (Ristic et al. 1998; Janowiak et al. 2002). It was shown that treatment with ABA decreased the cold injury of maize seedlings (Aroca et al. 2003; Pál et al. 2011).

In the auxin signaling pathway, the sharpest differences between the lines were visible at the level of auxin reception, potentially activated in all variants of S68911 predominantly in the cold. The potential expression of ARF and transport inhibitor response 1/auxin signaling F-box (TIR1/AFB) suggests the activation of the response to auxin in the coldtolerant line. The pathways are presented in Online Resource 10, and source data are given in Online Resource 11.

It should be noted that the presented metabolic pathway analyses are limited because not all maize genes are annotated and included in pathways (hence absence of ABA, ethylene, and cytokinin signaling in our results).

\section{Homeotic Genes Could Have a Role in the Cold-Stress Response}

In the context of hormonal regulation, two potentially expressed genes are notable, KN1 (GRMZM2G017087) and WUS1 (GRMZM2G047448). A subnetwork composed of mainly homeotic genes clustered around $\mathrm{KN} 1$ and WUS1 was present at all S68911 stages (Figs. 1 and 2). Potential expression of $K N 1$ is in concert with its nearly fivefold upregulation in cold in ETH-DH7 maize line (Sobkowiak et al. 2014). According to the literature, KN1 and WUS1 are expressed predominantly in the shoot meristem, and $K N 1$ also in generative organs and developing stem (Jackson et al. 1994; Stelpflug et al. 2016). The primary function of KN1 is shoot meristem maintenance by repressing GA synthesis (Kerstetter et al. 1997). The expression levels of KN1 and WUS1 in microarray studies on maize stress response were checked using the Gene Expression Omnibus database (Barrett et al. 2013). GEO2R module and a false discovery rate corrected $p$ value cutoff of 0.05 were used. KN1 expression was activated above twofold during drought stress in leaves (Hayano-Kanashiro et al. 2009) and shoots (Zheng et al. 2010). Similar droughtresponse of maize was shown by Nelissen et al. (2018). The expression of $K N 1$ was also more than fourfold upregulated in maize stems challenged by the European corn borer (Dafoe et al. 2013).

Data on WUS1 expression are scarce. Nevertheless, in rice seedlings, orthologous OsWUS was highly upregulated after $12 \mathrm{~h}$ of drought but not after cold or salinity stress (Cheng et al. 2014). These results suggest that KN1 and WUS1 may have a role in the stress response, but its elucidation requires further study. In keeping with growth inhibition and potential GA degradation, KN1 was shown to activate the GA catabolism gene gibberellin 2-beta-dioxygenase 1 (GA2OX1, Bolduc et al. 2012). Moreover, in the network for VE stage, $\mathrm{KN} 1$ interacted with a repressor of GA signaling, Dwarf plant 9 (D9, Lawit et al. 2010).

KN1 was shown to repress the auxin signaling pathway (Bolduc et al. 2012), potentially activated in the leaves of cold-stressed S68911 plants. Auxin and KN1 act antagonistically in plant development, what complicates the interpretation of our results. However, a positive role of auxin in the cold response was found in cold-tolerant (Zhao et al. 2015) 
and sensitive rice varieties (Jain and Khurana 2009; Du et al. 2013), and cold-tolerant cultivar of the C4 plant Digitaria eriantha (Garbero et al. 2012).

\section{Conclusions}

The chromatin-level analysis suggests that the superior performance of the S68911 maize line in cold is dependent on the defense-favoring partitioning of resources and avoidance of water stress. This avoidance is manifested on the phenotype level by the xeromorphic growth form (Grzybowski et al. 2019), which was also found for other cold-tolerant maize lines. It can be hypothesized that the underlying mechanism involves a balance of GAs and JA in favor of the latter. This change would enable seedlings to arrest growth, secure resources, and resume growth after the end of cold stress. The role of sustained developmental processes in cold tolerance is supported by our previous molecular and physiological level analyses (Sobkowiak et al. 2016; Grzybowski et al. 2019). This study concerned the most basic level of gene expression regulation; therefore, it requires further confirmation. Nevertheless, we presented several candidates for further studies on cold stress tolerance in maize and possibly in related species.

Acknowledgments The authors would like to thank Dr. Marcin Grzybowski for the growth chamber setup, help during plant growth, and many fruitful discussions.

Author Contributions Study conception and design were performed by Maciej Jończyk and Paweł Sowiński. Material preparation and data collection were performed by Maciej Jończyk and Alicja Sobkowiak and Joanna Trzcinska-Danielewicz. Analysis was performed by Maciej Jończyk and Paweł Sowiński. The first draft of the manuscript was written by Maciej Jończyk, and all authors commented on previous versions of the manuscript. All authors read and approved the final manuscript.

Funding This study was funded by the National Science Centre, Poland (grant numbers: 2014/13/D/NZ9/04777 to M.J. and 2017/27/B/NZ9/ 00995 to P.S.).

Data Availability Raw sequencing files and NDR peak-calling results are available in the ArrayExpress database under accession number EMTAB-8401 (https://www.ebi.ac.uk/arrayexpress/experiments/EMTAB-8401/).

\section{Compliance with Ethical Standards}

Conflict of Interest The authors declare that they have no conflict of interest.

Open Access This article is licensed under a Creative Commons Attribution 4.0 International License, which permits use, sharing, adaptation, distribution and reproduction in any medium or format, as long as you give appropriate credit to the original author(s) and the source, provide a link to the Creative Commons licence, and indicate if changes were made. The images or other third party material in this article are included in the article's Creative Commons licence, unless indicated otherwise in a credit line to the material. If material is not included in the article's Creative Commons licence and your intended use is not permitted by statutory regulation or exceeds the permitted use, you will need to obtain permission directly from the copyright holder. To view a copy of this licence, visit http://creativecommons.org/licenses/by/4.0/.

\section{References}

Andrews S (2010) FastQC: a quality control tool for high throughput sequence data. Available online at: http://www.bioinformatics. babraham.ac.uk/projects/fastqc. Accessed 17 Apr 2015

Aroca R, Irigoyen JJ, Sánchez-Díaz M (2001) Photosynthetic characteristics and protective mechanisms against oxidative stress during chilling and subsequent recovery in two maize varieties differing in chilling sensitivity. Plant Sci 161:719-726. https://doi.org/10. 1016/S0168-9452(01)00460-5

Aroca R, Vernieri P, Irigoyen JJ, Sánchez-Díaz M, Tognoni F, Pardossi A (2003) Involvement of abscisic acid in leaf and root of maize (Zea mays L.) in avoiding chilling-induced water stress. Plant Sci 165: 671-679. https://doi.org/10.1016/S0168-9452(03)00257-7

Barrett T, Wilhite SE, Ledoux P, Evangelista C, Kim IF, Tomashevsky M, Marshall KA, Phillippy KH, Sherman PM, Holko M, Yefanov A, Lee H, Zhang N, Robertson CL, Serova N, Davis S, Soboleva A (2013) NCBI GEO: archive for functional genomics data sets - update. Nucleic Acids Res 41:D991-D995. https://doi.org/10.1093/ nar/gks 1193

Bilska-Kos A, Grzybowski M, Jończyk M, Sowiński P (2016) In situ localization and changes in the expression level of transcripts related to intercellular transport and phloem loading in leaves of maize (Zea mays L.) treated with low temperature. Acta Physiol Plant 38:123. https://doi.org/10.1007/s11738-016-2151-5

Bolduc N, Yilmaz A, Mejia-Guerra MK, Morohashi K, O’Connor D, Grotewold E, Hake S (2012) Unraveling the KNOTTED1 regulatory network in maize meristems. Genes Dev 26:1685-1690. https:// doi.org/10.1101/gad.193433.112

Bolger AM, Lohse M, Usadel B (2014) Trimmomatic: a flexible trimmer for Illumina sequence data. Bioinformatics 30:2114-2120. https:// doi.org/10.1093/bioinformatics/btu170

Borrego E, Kolomiets M (2016) Synthesis and functions of jasmonates in maize. Plants 5:41. https://doi.org/10.3390/plants5040041

Buti M, Pasquariello M, Ronga D, Milc JA, Pecchioni N, Ho VT, Pucciariello C, Perata P, Francia E (2018) Transcriptome profiling of short-term response to chilling stress in tolerant and sensitive Oryza sativa ssp Japonica seedlings. Funct Integr Genomic 18: 627-644. https://doi.org/10.1007/s10142-018-0615-y

Candaele J, Demuynck K, Mosoti D, Beemster GTS, Inze D, Nelissen H (2014) Differential methylation during maize leaf growth targets developmentally regulated genes. Plant Physiol 164:1350-1364. https://doi.org/10.1104/pp.113.233312

Cheng S, Huang Y, Zhu N, Zhao Y (2014) The rice WUSCHEL-related homeobox genes are involved in reproductive organ development, hormone signaling and abiotic stress response. Gene 549:266-274. https://doi.org/10.1016/j.gene.2014.08.003

Chinnusamy V, Zhu J, Zhu J-K (2007) Cold stress regulation of gene expression in plants. Trends Plant Sci 12:444-451. https://doi.org/ 10.1016/j.tplants.2007.07.002

Cline MS, Smoot M, Cerami E, Kuchinsky A, Landys N, Workman C, Christmas R, Avila-Campilo I, Creech M, Gross B, Hanspers K, Isserlin R, Kelley R, Killcoyne S, Lotia S, Maere S, Morris J, Ono K, Pavlovic V, Pico AR, Vailaya A, Wang PL, Adler A, Conklin BR, Hood L, Kuiper M, Sander C, Schmulevich I, Schwikowski B, Warner GJ, Ideker T, Bader GD (2007) Integration of biological 
networks and gene expression data using Cytoscape. Nat Protoc 2: 2366-2382. https://doi.org/10.1038/nprot.2007.324

Colebrook EH, Thomas SG, Phillips AL, Hedden P (2014) The role of gibberellin signalling in plant responses to abiotic stress. J Exp Biol 217:67-75. https://doi.org/10.1242/jeb.089938

Dafoe NJ, Thomas JD, Shirk PD, Legaspi ME, Vaughan MM, Huffaker A, Teal PE, Schmelz EA (2013) European corn borer (Ostrinia nubilalis) inducedresponses enhance susceptibility in maize. PLoS One 8(9): e73394. https://doi.org/10.1371/journal.pone.0073394

Du H, Liu H, Xiong L (2013) Endogenous auxin and jasmonic acid levels are differentially modulated by abiotic stresses in rice. Front Plant Sci 4:397. https://doi.org/10.3389/fpls.2013.00397

Foyer CH, Vanacker H, Gomez LD, Harbinson J (2002) Regulation of photosynthesis and antioxidant metabolism in maize leaves at optimal and chilling temperatures: review. Plant Physiol Bioch 40:659 668. https://doi.org/10.1016/S0981-9428(02)01425-0

Frascaroli E, Revilla P (2018) Genomics of cold tolerance in maize. In: Bennetzen J, Flint-Garcia S, Hirsch C, Tuberosa R (eds) The maize genome. Compendium of plant genomes. Springer, Cham, pp 287303. https://doi.org/10.1007/978-3-319-97427-9_17

Frith MC (2004) Detection of functional DNA motifs via statistical overrepresentation. Nucleic Acids Res 32:1372-1381. https://doi.org/10. 1093/nar/gkh299

Garbero M, Andrade A, Reinoso H, Fernandez B, Cuesta C, Granda V, Escudero C, Abdala G, Pedranzani H (2012) Differential effect of short-term cold stress on growth, anatomy, and hormone levels in cold-sensitive versus -resistant cultivars of Digitaria eriantha. Acta Physiol Plant 34:2079-2091. https://doi.org/10.1007/s11738-0121007-x

Grzybowski M, Adamczyk J, Jończyk M, Sobkowiak A, Szczepanik J, Frankiewicz K, Fronk J, Sowiński P (2019) Increased photosensitivity at early growth as a possible mechanism of maize adaptation to cold springs. J Exp Bot 70:2887-2904. https://doi.org/10.1093/jxb/ erz096

Haldimann P (1999) How do changes in temperature during growth affect leaf pigment composition and photosynthesis in Zea mays genotypes differing in sensitivity to low temperature? J Exp Bot 50: 543-550. https://doi.org/10.1093/jxb/50.333.543

Han S-K, Wagner D (2014) Role of chromatin in water stress responses in plants. J Exp Bot 65:2785-2799. https://doi.org/10.1093/jxb/ert403

Hayano-Kanashiro C, Calderón-Vázquez C, Ibarra-Laclette E, HerreraEstrella L, Simpson J (2009) Analysis of gene expression and physiological responses in three Mexican maize landraces under drought stress and recovery irrigation. PLoS ONE 4:e7531. https://doi.org/ 10.1371/journal.pone.0007531

Hehl R, Bülow L (2014) AthaMap web tools for the analysis of transcriptional and posttranscriptional regulation of gene expression in Arabidopsis thaliana. In: Staiger D (ed) Plant circadian networks. Methods in molecular biology (methods and protocols), vol 1158. Humana Press, New York, pp 139-156. https://doi.org/10.1007/ 978-1-4939-0700-7_9

Heinz S, Benner C, Spann N, Bertolino E, Lin YC, Laslo P, Cheng JX, Murre C, Singh H, Glass CK (2010) Simple combinations of lineage-determining transcription factors prime cis-regulatory elements required for macrophage and B cell identities. Mol Cell 38: 576-589. https://doi.org/10.1016/j.molcel.2010.05.004

Hodges DM, Andrews CJ, Johnson DA, Hamilton RI (1997) Antioxidant enzyme and compound responses to chilling stress and their combining abilities in differentially sensitive maize hybrids. Crop Sci 37: 857-863. https://doi.org/10.2135/cropsci 1997. $0011183 X 003700030027 x$

Hogan GJ, Lee C-K, Lieb JD (2006) Cell cycle-specified fluctuation of nucleosome occupancy at gene promoters. PLoS Genet 2:e158. https://doi.org/10.1371/journal.pgen.0020158

$\mathrm{Hu}$ Y, Zhang L, He S et al (2012) Cold stress selectively unsilences tandem repeats in heterochromatin associated with accumulation of H3K9ac. Plant Cell Environ 35:2130-2142. https://doi.org/10. 1111/j.1365-3040.2012.02541.x

Hu Y, Jiang L, Wang F, Yu D (2013) Jasmonate regulates the INDUCER OF CBF EXPRESSION-C-REPEAT BINDING FACTOR/DRE BINDING FACTOR 1 cascade and freezing tolerance in Arabidopsis. Plant Cell 25:2907-2924. https://doi.org/10.1105/tpc. 113.112631

Jackson D, Veit B, Hake S (1994) Expression of maize KNOTTED1 related homeobox genes in the shoot apical meristem predicts patterns of morphogenesis in the vegetative shoot. Development 120: 405-413

Jahnke LS, Hull MR, Long SP (1991) Chilling stress and oxygen metabolizing enzymes in Zea mays and Zea diploperennis. Plant Cell Environ 14:97-104. https://doi.org/10.1111/j.1365-3040.1991. tb01375.x

Jain M, Khurana JP (2009) Transcript profiling reveals diverse roles of auxin-responsive genes during reproductive development and abiotic stress in rice. FEBS J 276:3148-3162. https://doi.org/10.1111/j. 1742-4658.2009.07033.x

Janowiak F, Maas B, Dörffling K (2002) Importance of abscisic acid for chilling tolerance of maize seedlings. J Plant Physiol 159:635-643. https://doi.org/10.1078/0176-1617-0638

Joets J, Vitte C, Charcosset A (2018) Draft assembly of the F2 European maize genome sequence and its comparison to the $\mathrm{B} 73$ genome sequence: a characterization of genotype-specific regions. In: Bennetzen J, Flint-Garcia S, Hirsch C, Tuberosa R (eds) The maize genome. Compendium of plant genomes. Springer, Cham, pp 3-12. https://doi.org/10.1007/978-3-319-97427-9 1

Kerstetter RA, Laudencia-Chingcuanco D, Smith LG, Hake S (1997) Loss-of-function mutations in the maize homeobox gene, knotted1, are defective in shoot meristem maintenance. Development 124: 3045-3054

Kingston-Smith AH, Foyer CH (2000) Bundle sheath proteins are more sensitive to oxidative damage than those of the mesophyll in maize leaves exposed to paraquat or low temperatures. J Exp Bot 51:123 130. https://doi.org/10.1093/jexbot/51.342.123

Langmead B, Salzberg SL (2012) Fast gapped-read alignment with Bowtie 2. Nat Methods 9:357-359. https://doi.org/10.1038/nmeth. 1923

Lawit SJ, Wych HM, Xu D, Kundu S, Tomes DT (2010) Maize DELLA proteins dwarf plant8 and dwarf plant9 as modulators of plant development. Plant Cell Physiol 51:1854-1868. https://doi.org/10. 1093/pcp/pcq153

Lee T-M, Lur H-S, Lin Y-H, Chu C (1996) Physiological and biochemical changes related to methyl jasmonate-induced chilling tolerance of rice (Oryza sativa L.) seedlings. Plant Cell Environ 19:65-74. https://doi.org/10.1111/j.1365-3040.1996.tb00227.x

Leipner J, Stamp P (2009) Chilling stress in maize seedlings. In: Bennetzen JL, Hake SC (eds) Handbook of maize: its biology. Springer, New York, pp 291-310. https://doi.org/10.1007/978-0387-79418-1_15

Li H, Handsaker B, Wysoker A, Fennell T, Ruan J, Homer N, Marth G, Abecasis G, Durbin R (2009) The sequence alignment/map format and SAMtools. Bioinformatics 25:2078-2079. https://doi.org/10. 1093/bioinformatics/btp352

Li Z, Hu G, Liu X, Zhou Y, Li Y, Zhang X, Yuan X, Zhang Q, Yang D, Wang T, Zhang Z (2016) Transcriptome sequencing identified genes and gene ontologies associated with early freezing tolerance in maize. Front Plant Sci 7:1477. https://doi.org/10.3389/fpls.2016. 01477

Lidon FC, Loureiro AS, Vieira DE, Bilhó EA, Nobre P, Costa R (2001) Photoinhibition in chilling stressed wheat and maize. Photosynthetica 39:161-166. https://doi.org/10.1023/A: 1013726303948

Liu S, Wang X, Wang H, Xin H, Yang X, Yan J, Li J, Tran LSP, Shinozaki K, Yamaguchi-Shinozaki K, Qin F (2013) Genome- 
wide analysis of ZmDREB genes and their association with natural variation in drought tolerance at seedling stage of Zea mays L. PLoS Genet 9:e1003790. https://doi.org/10.1371/journal.pgen.1003790

Long SP (1983) C4 photosynthesis at low temperatures. Plant Cell Environ 6:345-363. https://doi.org/10.1111/1365-3040. ep11612141

Maere S, Heymans K, Kuiper M (2005) BiNGO: a Cytoscape plugin to assess overrepresentation of Gene Ontology categories in Biological Networks. Bioinformatics 21:3448-3449. https://oi.org/10.1093/ bioinformatics/bti551

Mathelier A, Zhao X, Zhang AW, Parcy F, Worsley-Hunt R, Arenillas DJ, Buchman S, Chen CY, Chou A, Ienasescu H, Lim J, Shyr C, Tan G, Zhou M, Lenhard B, Sandelin A, Wasserman WW (2014) JASPAR 2014: an extensively expanded and updated open-access database of transcription factor binding profiles. Nucleic Acids Res 42:D142-D147. https://doi.org/10.1093/nar/gkt997

Naithani S, Preece J, D’Eustachio P et al (2017) Plant Reactome: a resource for plant pathways and comparative analysis. Nucleic Acids Res 45:D1029-D1039. https://doi.org/10.1093/nar/gkw932

Nelissen H, Sun X-H, Rymen B, Jikumaru Y, Kojima M, Takebayashi Y, Abbeloos R, Demuynck K, Storme V, Vuylsteke M, de Block J, Herman D, Coppens F, Maere S, Kamiya Y, Sakakibara H, Beemster GTS, Inzé D (2018) The reduction in maize leaf growth under mild drought affects the transition between cell division and cell expansion and cannot be restored by elevated gibberellic acid levels. Plant Biotechnol J 16:615-627. https://doi.org/10.1111/pbi. 12801

Nguyen HT, Leipner J, Stamp P, Guerra-Peraza O (2009) Low temperature stress in maize (Zea mays L.) induces genes involved in photosynthesis and signal transduction as studied by suppression subtractive hybridization. Plant Physiol Bioch 47:116-122. https://doi.org/ 10.1016/j.plaphy.2008.10.010

O'Shaughnessy PJ, Monteiro A, Fowler PA (2011) Identification of stable endogenous reference genes for real-time PCR in the human fetal gonad using an external standard technique. Mol Hum Reprod 17:620-625. https://doi.org/10.1093/molehr/gar032

Oka R, Zicola J, Weber B, Anderson SN, Hodgman C, Gent JI, Wesselink JJ, Springer NM, Hoefsloot HCJ, Turck F, Stam M (2017) Genome-wide mapping of transcriptional enhancer candidates using DNA and chromatin features in maize. Genome Biol 18:137. https://doi.org/10.1186/s13059-017-1273-4

Omidbakhshfard MA, Winck FV, Arvidsson S, Riaño-Pachón DM, Mueller-Roeber B (2014) A step-by-step protocol for formaldehyde-assisted isolation of regulatory elements from Arabidopsis thaliana: FAIRE protocol for plants. J Integr Plant Biol 56:527-538. https://doi.org/10.1111/jipb.12151

Osborne CP, Sack L (2012) Evolution of C4 plants: a new hypothesis for an interaction of $\mathrm{CO}_{2}$ and water relations mediated by plant hydraulics. Philos T Roy Soc B 367:583-600. https://doi.org/10.1098/rstb. 2011.0261

Pál M, Janda T, Szalai G (2011) Abscisic acid may alter the salicylic acidrelated abiotic stress response in maize. J Agron Crop Sci 197:368377. https://doi.org/10.1111/j.1439-037X.2011.00474.x

Parkinson H, Sarkans U, Kolesnikov N, Abeygunawardena N, Burdett T, Dylag M, Emam I, Farne A, Hastings E, Holloway E, Kurbatova N, Lukk M, Malone J, Mani R, Pilicheva E, Rustici G, Sharma A, Williams E, Adamusiak T, Brandizi M, Sklyar N, Brazma A (2010) ArrayExpress update - an archive of microarray and highthroughput sequencing-based functional genomics experiments. Nucleic Acids Res 39:D1002-D1004. https://doi.org/10.1093/nar/ gkq1040

Perduns R, Horst-Niessen I, Peterhansel C (2015) Photosynthetic genes and genes associated with the $\mathrm{C} 4$ trait in maize are characterized by a unique class of highly regulated histone acetylation peaks on upstream promoters. Plant Physiol 168:1378-1388. https://doi.org/10. 1104/pp. 15.00934
R Development Core Team (2019) R: a language and environment for statistical computing. R Foundation for Statistical Computing, Vienna

Ramírez F, Ryan DP, Grüning B, Bhardwaj V, Kilpert F, Richter AS, Heyne S, Dündar F, Manke T (2016) deepTools2: a next generation web server for deep-sequencing data analysis. Nucleic Acids Res 44:W160-W165. https://doi.org/10.1093/nar/gkw257

Ristic Z, Yang G, Sterzinger A, Zhang L (1998) Higher chilling tolerance in maize is not always related to the ability for greater and faster abscisic acid accumulation. J Plant Physiol 153:154-162. https:// doi.org/10.1016/S0176-1617(98)80059-X

Ritchie SW, Hanway JJ, Benson GO (1986) How a corn plant develops, special report No. 48. Iowa State University of Science and Technology. http://publications.iowa.gov/18027/1/How\%20a\% 20corn\%20plant\%20develops001.pdf. Accessed 23 October 2019

Riva-Roveda L, Escale B, Giauffret C, Périlleux C (2016) Maize plants can enter a standby mode to cope with chilling stress. BMC Plant Biol 16:212. https://doi.org/10.1186/s12870-016-0909-y

Rodgers-Melnick E, Vera DL, Bass HW, Buckler ES (2016) Open chromatin reveals the functional maize genome. Proc Natl Acad Sci U S A 113:E3177-E3184. https://doi.org/10.1073/pnas.1525244113

Roy D, Paul A, Roy A, Ghosh R, Ganguly P, Chaudhuri S (2014) Differential acetylation of histone $\mathrm{H} 3$ at the regulatory region of OSDREB $1 b$ promoter facilitates chromatin remodelling and transcription activation during cold stress. PLoS One 9:e100343. https://doi.org/10.1371/journal.pone.0100343

Schmittgen TD, Livak KJ (2008) Analyzing real-time PCR data by the comparative CT method. Nat Protoc 3:1101-1108. https://doi.org/ 10.1038/nprot.2008.73

Schnable PS, Ware D, Fulton RS, Stein JC, Wei F, Pasternak S, Liang C, Zhang J, Fulton L, Graves TA, Minx P, Reily AD, Courtney L, Kruchowski SS, Tomlinson C, Strong C, Delehaunty K, Fronick C, Courtney B, Rock SM, Belter E, du F, Kim K, Abbott RM, Cotton M, Levy A, Marchetto P, Ochoa K, Jackson SM, Gillam B, Chen W, Yan L, Higginbotham J, Cardenas M, Waligorski J, Applebaum E, Phelps L, Falcone J, Kanchi K, Thane T, Scimone A, Thane N, Henke J, Wang T, Ruppert J, Shah N, Rotter K, Hodges J, Ingenthron E, Cordes M, Kohlberg S, Sgro J, Delgado B, Mead K, Chinwalla A, Leonard S, Crouse K, Collura K, Kudrna D, Currie J, He R, Angelova A, Rajasekar S, Mueller T, Lomeli R, Scara G, Ko A, Delaney K, Wissotski M, Lopez G, Campos D, Braidotti M, Ashley E, Golser W, Kim H, Lee S, Lin J, Dujmic Z, Kim W, Talag J, Zuccolo A, Fan C, Sebastian A, Kramer M, Spiegel L, Nascimento L, Zutavern T, Miller B, Ambroise C, Muller S, Spooner W, Narechania A, Ren L, Wei S, Kumari S, Faga B, Levy MJ, McMahan L, van Buren P, Vaughn MW, Ying K, Yeh CT, Emrich SJ, Jia Y, Kalyanaraman A, Hsia AP, Barbazuk WB, Baucom RS, Brutnell TP, Carpita NC, Chaparro C, Chia JM, Deragon JM, Estill JC, Fu Y, Jeddeloh JA, Han Y, Lee H, Li P, Lisch DR, Liu S, Liu Z, Nagel DH, McCann MC, SanMiguel P, Myers AM, Nettleton D, Nguyen J, Penning BW, Ponnala L, Schneider KL, Schwartz DC, Sharma A, Soderlund C, Springer NM, Sun Q, Wang H, Waterman M, Westerman R, Wolfgruber TK, Yang L, Yu Y, Zhang L, Zhou S, Zhu Q, Bennetzen JL, Dawe RK, Jiang J, Jiang N, Presting GG, Wessler SR, Aluru S, Martienssen RA, Clifton SW, McCombie WR, Wing RA, Wilson RK (2009) The B73 maize genome: complexity, diversity, and dynamics. Science 326:1112-1115. https://doi.org/10.1126/science. 1178534

Shan X, Li Y, Jiang Y, Jiang Z, Hao W, Yuan Y (2013) Transcriptome profile analysis of maize seedlings in response to high-salinity, drought and cold stresses by deep sequencing. Plant Mol Biol Rep 31:1485-1491. https://doi.org/10.1007/s11105-013-0622-z

Sobkowiak A, Jończyk M, Jarochowska E, Biecek P, TrzcinskaDanielewicz J, Leipner J, Fronk J, Sowiński P (2014) Genomewide transcriptomic analysis of response to low temperature reveals 
candidate genes determining divergent cold-sensitivity of maize inbred lines. Plant Mol Biol 85:317-331. https://doi.org/10.1007/ s11103-014-0187-8

Sobkowiak A, Jończyk M, Adamczyk J, Szczepanik J, Solecka D, Kuciara I, Hetmańczyk K, Trzcinska-Danielewicz J, Grzybowski M, Skoneczny M, Fronk J, Sowiński P (2016) Molecular foundations of chilling-tolerance of modern maize. BMC Genomics 17: 125. https://doi.org/10.1186/s12864-016-2453-4

Sowiński P, Rudzińska-Langwald A, Kobus P (2003) Changes in plasmodesmata frequency in vascular bundles of maize seedling leaf induced by growth at sub-optimal temperatures in relation to photosynthesis and assimilate export. Environ Exp Bot 50:183-196. https://doi.org/10.1016/S0098-8472(03)00021-2

Stelpflug SC, Sekhon RS, Vaillancourt B, Hirsch CN, Buell CR, de Leon N, Kaeppler SM (2016) An expanded maize gene expression atlas based on RNA sequencing and its use to explore root development. Plant Genome-US 9:9. https://doi.org/10.3835/plantgenome2015. 04.0025

Strigens A, Freitag NM, Gilbert X, Grieder C, Riedelsheimer C, Schrag TA, Messmer R, Melchinger AE (2013) Association mapping for chilling tolerance in elite flint and dent maize inbred lines evaluated in growth chamber and field experiments. Plant Cell Environ 36: 1871-1887. https://doi.org/10.1111/pce.12096

Swanson-Wagner RA, Eichten SR, Kumari S, Tiffin P, Stein JC, Ware D, Springer NM (2010) Pervasive gene content variation and copy number variation in maize and its undomesticated progenitor. Genome Res 20:1689-1699. https://doi.org/10.1101/gr.109165.110

Szklarczyk D, Morris JH, Cook H, Kuhn M, Wyder S, Simonovic M, Santos A, Doncheva NT, Roth A, Bork P, Jensen LJ, von Mering C (2017) The STRING database in 2017: quality-controlled proteinprotein association networks, made broadly accessible. Nucleic Acids Res 45:D362-D368. https://doi.org/10.1093/nar/gkw937

Trapnell C, Pachter L, Salzberg SL (2009) TopHat: discovering splice junctions with RNA-Seq. Bioinformatics 25:1105-1111. https://doi. org/10.1093/bioinformatics/btp120

Trapnell C, Williams BA, Pertea G, Mortazavi A, Kwan G, van Baren MJ, Salzberg SL, Wold BJ, Pachter L (2010) Transcript assembly and quantification by RNA-Seq reveals unannotated transcripts and isoform switching during cell differentiation. Nat Biotechnol 28: 511-515. https://doi.org/10.1038/nbt.1621

Tsompana M, Buck MJ (2014) Chromatin accessibility: a window into the genome. Epigenet Chromatin 7:33. https://doi.org/10.1186/ 1756-8935-7-33

Vera DL, Madzima TF, Labonne JD, Alam MP, Hoffman GG, Girimurugan SB, Zhang J, McGinnis KM, Dennis JH, Bass HW (2014) Differential nuclease sensitivity profiling of chromatin reveals biochemical footprints coupled to gene expression and functional DNA elements in maize. Plant Cell 26:3883-3893. https://doi. org/10.1105/tpc.114.130609

Verheul MJ, Picatto C, Stamp P (1996) Growth and development of maize (Zea mays L.) seedlings under chilling conditions in the field. Eur J Agron 5:31-43. https://doi.org/10.1016/S1161-0301(96) 02007-2
Walsh JR, Schaeffer ML, Zhang P, Rhee SY, Dickerson JA, Sen TZ (2016) The quality of metabolic pathway resources depends on initial enzymatic function assignments: a case for maize. BMC Syst Biol 10:129. https://doi.org/10.1186/s12918-016-0369-x

Wang C-T, Yang Q, Wang C-T (2011) Isolation and functional characterization of $\mathrm{ZmDBP} 2$ encoding a dehydration-responsive elementbinding protein in Zea mays. Plant Mol Biol Rep 29:60-68. https:// doi.org/10.1007/s11105-010-0210-4

Wang P, Zhao L, Hou H, Zhang H, Huang Y, Wang Y, Li H, Gao F, Yan S, Li L (2015) Epigenetic changes are associated with programmed cell death induced by heat stress in seedling leaves of Zea mays. Plant Cell Physiol 56:965-976. https://doi.org/10.1093/pcp/pcv023

Wimalanathan K, Friedberg I, Andorf CM, Lawrence-Dill CJ (2018) Maize GO annotation - methods, evaluation, and review (maizeGAMER). Plant Direct 2:e00052. https://doi.org/10.1002/pld3.52

Yan Y, Huang P-C, Borrego E, Kolomiets M (2014) New perspectives into jasmonate roles in maize. Plant Signal Behav 9:e970442. https://doi.org/10.4161/15592316.2014.970442

Yilmaz A, Nishiyama MY, Fuentes BG, Souza GM, Janies D, Gray J, Grotewold E (2009) GRASSIUS: a platform for comparative regulatory genomics across the grasses. Plant Physiol 149:171-180. https://doi.org/10.1104/pp.108.128579

Zhang J, Simmons C, Yalpani N, Crane V, Wilkinson H, Kolomiets M (2005) Genomic analysis of the 12-oxo-phytodienoic acid reductase gene family of Zea mays. Plant Mol Biol 59:323-343. https://doi. org/10.1007/s11103-005-8883-Z

Zhang Y, Fu J, Gu R, Wang J, Chen X, Jia J, Zhang J, Wang G (2009) Isolation and analysis of cold stress inducible genes in Zea mays by suppression subtractive hybridization and cDNA macroarray. Plant Mol Biol Rep 27:38-49. https://doi.org/10.1007/s11105-008-0055-

Zhang L, Gao M, Hu J, Zhang X, Wang K, Ashraf M (2012) Modulation role of abscisic acid (ABA) on growth, water relations and glycinebetaine metabolism in two maize (Zea mays L.) cultivars under drought stress. Int J Mol Sci 13:3189-3202. https://doi.org/ 10.3390/ijms13033189

Zhao L, Wang P, Yan S, Gao F, Li H, Hou H, Zhang Q, Tan J, Li L (2014) Promoter-associated histone acetylation is involved in the osmotic stress-induced transcriptional regulation of the maize ZmDREB2A gene. Physiol Plantarum 151:459-467. https://doi. org/10.1111/ppl.12136

Zhao J, Zhang S, Yang T, Zeng Z, Huang Z, Liu Q, Wang X, Leach J, Leung H, Liu B (2015) Global transcriptional profiling of a coldtolerant rice variety under moderate cold stress reveals different cold stress response mechanisms. Physiol Plantarum 154:381-394. https://doi.org/10.1111/ppl.12291

Zheng J, Fu J, Gou M, Huai J, Liu Y, Jian M, Huang Q, Guo X, Dong Z, Wang H, Wang G (2010) Genome-wide transcriptome analysis of two maize inbred lines under drought stress. Plant Mol Biol 72:407421. https://doi.org/10.1007/s11103-009-9579-6

Publisher's Note Springer Nature remains neutral with regard to jurisdictional claims in published maps and institutional affiliations. 